\title{
Muhasebe Bilgisinin Çevresi ve Muhasebe Bilgi Kalitesini Artıran ve Azaltan Faktörler*
}

\author{
Environment of Accounting Information and Factors That Increase and Reduce the Quality of Accounting \\ Information
}

\author{
Mehmet Demir **1(D) Derya Onocak 2(D) \\ ${ }^{1}$ Finance and Banking Department, Sivas Cumhuriyet University, Sivas, Turkey \\ ${ }^{2}$ Gurun Vocational School, Sivas Cumhuriyet University, Sivas, Turkey
}

\begin{abstract}
Received: 17.06 .2021
Accepted: 27.09.2021

This article was checked by intihal.net

Öz

Günümüzde, ekonomik girdilerden biri haline gelen finansal bilgi, işletmelerde en çok muhasebe sistemi tarafından üretilmekte ve işletme paydaşlarına sunulmaktadır. Sunulan bu bilgileri, bilgi kullanıcısı olarak da adlandırılan paydaşlar, ihtiyaçları doğrultusunda değerlendirmekte ve yatırım, kredi, vergilendirme, kontrol, planlama gibi konularda geleceğe yönelik kararlar almaktadırlar. Alınan kararların isabetli olması ve kaynakların etkin kullanımı, kararların dayanağı olan bilgilerin kalitesine bağlıdır. Bu yönüyle meslek mensuplarının faaliyetleri ekonomik kalkınmaya da doğrudan ve önemli bir düzeyde katkı sağlamaktadır.

Bu çalışmanın amacı, muhasebe bilgisinin çevresini açıklamak ve muhasebe bilgi kalitesini artıran ve azaltan faktörleri ortaya koymaktır. Bu amaçla çalışmada, öncelikle muhasebe bilgi kalitesinin önemi üzerinde durulmuştur. Ardından muhasebe bilgi kalitesinin şekillendiği çevresel yapıyı oluşturan unsurlar hakkında bilgiler verilmiştir. Son olarak bu konularda yapılan çalışmalar incelenmiş ve muhasebe bilgi kalitesini olumlu veya olumsuz yönde etkileyen faktörler açıklanmaya çalışılmıştır. Muhasebe bilgi kalitesinin belirtilen faktörlerin varlığında artacağı söylenebilir: Bağımsız, tarafsız ve mesleki yeterliliğe sahip muhasebe mensuplarına sahip olmak; tekdüzen muhasebe sistemine, muhasebe ilke ve standartlarına ve yasalara uygun bilgiler üretmek; etkin bir iç kontrol ve iç denetim sistemi kurmak. Ancak bu konularda taviz verildiğinde ve yasalardaki eksiklik ve esnekliklerin belli bir grubun çıkarı doğrultusunda kullanıldığı ve etik problemlerin yaşandığı durumlarda muhasebe bilgilerinin kalite düzeyinin düşük olacağı da bir gerçektir.
\end{abstract}

Anahtar Kelimeler: Muhasebe Bilgisi, Muhasebe Bilgi Kalitesi, Muhasebe Bilgisinin Çevresi, Muhasebe Meslek Mensubu

\section{Abstract}

Today, financial information, which has become one of the economic inputs, is mostly produced by the accounting system in enterprises and presented to the business stakeholders. Stakeholders, also known as information users, evaluate this information in line with their needs and make future-oriented decisions on subjects such as investment, credit, taxation, control, and planning. The accuracy of the decisions made and the efficient use of resources depend on the quality of the information that is the basis of the decisions. In this respect, the activities of the members of the profession contribute directly and significantly to economic development.

The purpose of this study is to explain the environment of accounting information and to reveal the factors that increase and decrease the quality of accounting information. For this purpose, the study focused primarily on the importance of accounting information quality. Then, information was given about the elements that make up the environmental structure in which the accounting information quality is formed. Finally, the studies conducted on these issues have been examined and the factors affecting the accounting information quality in a positive or negative way have been tried to be explained. It can be said that the quality of accounting information will increase in the presence of the following factors: Having independent, impartial and professionally qualified accountants; to produce information in accordance with the uniform accounting system, accounting principles and standards and laws; to establish an effective internal control and internal audit system. However, it is also a fact that the quality level of accounting information will be low when concessions are made on these issues and in cases where the deficiencies and flexibility in the laws are used for the benefit of a certain group and ethical problems are experienced.

Keywords: Accounting Information, Accounting Knowledge Quality, Environment of Accounting Information, Accounting Professional

Demir, M. \& Onocak, D. (2021). Muhasebe Bilgisinin Çevresi ve Muhasebe Bilgi Kalitesini Artıran ve Azaltan Faktörler. Journal of Academic Value Studies, 7(3), 210-230. http://dx.doi.org/10.29228/javs.51813

\footnotetext{
* Bu çalışma, Prof. Dr. Mehmet DEMIR'in danışmanlığında Öğr. Gör. Derya ONOCAK'ın hazırladığı “SMMM'lerin Muhasebe Sistemine, Vergi Mevzuatına ve Etik illkelere Uyum Düzeylerinin YMM'ler tarafından Değerlendirilmesi Üzerine Nitel Bir Araştırma” adlı doktora tezinden yararlanılarak hazırlanmıştır.

Yine bu çalışma, 9-11 Haziran 2021 tarihleri arasında, Kırgızistan-Türkiye Manas Üniversitesi ev sahipliğinde düzenlenen 2. Uluslararası İktisadi ve İdari Bilimler Kongresi'nde sunulan çalışmanın detaylı olarak gözden geçirilmiş ve geliştirilmiş halidir.

** E-mail address: mehmet_demir01@hotmail.com (Corresponding Author)
} 


\section{Giriş}

Işletmelerin başarısında ve hedeflerine ulaşmasında, çağımızın en önemli ve değerli kaynağı olan finansal bilgi, ekonominin yapı taşları olan işletmeler nezdinde en çok muhasebe bilgi sistemi tarafından üretilmekte ve raporlar halinde işletme içi ve dışı bilgi kullanıcılarına sunulmaktadır.

Bilgi üretimi gibi önemli ve zahmetli bir hizmetin sunulduğu muhasebe mesleği, hem elde edilmesi hem de yürütülmesi zor olan ve sabır gerektiren mesleklerden biridir. Meslek, üretip sunduğu muhasebe bilgisiyle işletmeyle ilgili tarafların karar alma aşamalarına değerli katkılar sağlamaktadır. Muhasebe mesleği muhasebe, finans, hukuk, işletme, iletişim, önsezi ve daha birçok alanın harmanlandığı çok komplike bir meslektir.

Sistemli olarak bir süreç dâhilinde üretilen muhasebe bilgileri, tüm ilgililerin benzer anlamlar yükleyeceği raporlarda, işletmenin faaliyet sonuçlarının, nakit akışlarının, mali ve ekonomik yapısının anlaşıımasını sağlayacak şekilde özetlenerek sunulmaktadır. Sunulan bu bilgiler bir taraftan planlama, kontrol ve performans değerleme ile ilgili olarak yöneticilerin sorumluluklarını etkin bir şekilde yerine getirmesine yardımcı olurken diğer taraftan diğer menfaat grupları için ortaklı̆ın devamı, yeni yatııımlara yönelme, kredi verme gibi karar almalarında yardımcı olmaktadır.

Üretilen muhasebe bilgilerinin kalitesi, alınacak kararların isabet derecesini de çok yakından etkilemektedir. Bundan dolayı bilgi kalitesini artıracak faktörlerin geliştirilmesi ve uygulanması buna karşılık azaltan faktörlerin etkisinin ise ortadan kaldırılması önemlidir. Bu önem, muhasebe sistemince üretilen bilginin etkilediği kişi ve kurumların farklılığı ve çokluğu düşünüldüğünde daha da artmaktadır. Zira bu bilgi, ekonomik boyutlu olup kaynakların verimli kullanımına kapı aralamaktadır. Bu yönüyle intiyaca uygun olarak üretilen ve gerçeği yansıtan dolayısıyla kalitesi yüksek muhasebe bilgilerinin ilgililerin kullanımına sunulması ekonomik kalkınmaya da doğrudan ve önemli bir düzeyde katkı sağlamaktadır.

Bu çalışmada; muhasebe bilgi kalitesinin önemine, muhasebe bilgisini çevreleyen yapıya, bilgi kalitesini olumlu veya olumsuz etkileyen faktörlere değinilmiş bu faktörlerin bazılarıyla ilgili olarak gerçekleştirilen ampirik çalışmaların sonuçlarına da yer verilmiştir.

\section{Muhasebe Bilgi Kalitesi ve Önemi}

"Kalite" kavramı, bir şeyin nitelikli olması anlamına gelen Latince "qualis" kelimesinden türetilmiştir. Kalite "bir ürün veya hizmetin belirlenen gereksinimleri karşılayabilmesini sağlayan nitelik ve özeliklerin tümü, kullanıma uygunluk" olarak tanımlanmaktır (https://sozluk.gov.tr, 2020). Crosby (1979), kaliteyi ihtiyaca uygunluk olarak tanımlar. Crosby'nin kalite yaklaşımı, bilgi üretiminde daha çok işletme dışındaki bilgi kullanıılarının beklentilerine odaklanılan stratejik bir yaklaşımdır. Bu tanımlardan hareketle bilgi kalitesini, kullanıma uygun bilgi olarak tanımlamak mümkündür.

Muhasebe bilgi kalitesi için ise genel kabul görmüş kesin bir tanım yapmak zordur. Literatürde muhasebe bilgi kalitesi üzerine birçok çalışma yapılmış ve bu çalışmalarda, çalışmanın amacına göre uyarlanan farklı tanımlar ortaya konulmuştur. Chen vd. muhasebe bilgi kalitesini, finansal tablolarda yer alan bilgilerin gerçeğe uygun, doğru ve hassas olması şeklinde tanımlarken (Chen vd, 2010:222) Callen vd. yatırımcıların, finansal tablolar aracılığıyla işletmenin, gelecekteki nakit akışları konusunda açıkça bilgilendirilmesi olarak tanımlamaktadır (Callen vd, 2013:269). Diğer bir tanıma göre muhasebe bilgi kalitesi, finansal tablo kullanıcıları nezdinde, finansal tablo unsurlarının gerçek değerleri ile tablolara yansıtıldığının değerlendirilmesidir (Pounder, 2013:18).

27/10/2018 tarihinde yayımlanan ve finansal raporları hazırlayanlara tutarlı muhasebe politikaları geliştirilmesi konusunda; ilgili tüm taraflara standartların anlaşıması ve yorumlaması konusunda yardımcı olmak amacıyla oluşturulmuş rehber niteliğindeki bir düzenleme olan "Finansal Raporlamaya Illişkin Kavramsal Çerçeve"de, faydalı finansal bilgilerin taşıması gereken temel ve destekleyici nitelikler sıralanarak, muhasebe bilgilerinin kalitesi üzerine önemli açıklamalar getirilmiştir. Temel ve destekleyici bu nitelikler aşağıdaki gibi açıklanabilir:

İhtiyaca Uygunluk: "Finansal tablolarda sunulan bilginin finansal tablo kullanıcılarının karar alma ihtiyaçlarını karşılayacak nitelikte olmasıdır." (BOBi FRS, md. 1.8) "Finansal bilgi tahmin değerine veya doğrulama değerine sahipse kullanıcılar tarafından verilen kararları etkileme gücüne sahiptir." (Kavramsal Çerçeve)

Muhasebe bilgilerinin, ilgili taraflarca kullanılarak gelecek hakkında beklentilerini şekillendirebilmeleri ve geçmişteki tahminlerini gerektiğinde doğrulayıp değiştirebilmeleri için, tahmin ve teyit etme değerini taşımaları gerekir. Tahmin değeri, tahminle gerçekleşenin birebir örtüşmesini çoğunlukla sağlamaz. Ancak gerçekleşeni tahmin etme olasılı̆ıını artırır (Akdoğan \& Tenker, 2010:44). 
Gerçeğe Uygun Sunum: Finansal bilgi, sunmayı amaçladığı ekonomik olayları gerçeğe uygun bir şekilde sunmalıdır. Bunun tamamıyla sağlanabilmesi için bilgi, olabilecek en yüksek düzeyde tam, tarafsız ve hatasız olmalıdır (Kavramsal Çerçeve).

Tam bir sunum; işletmenin tüm mali nitelikli olaylarının, faaliyet sonuçlarının ve gerekli açıklamaların finansal tablolarda bulunmasını ifade etmektedir (Alkan, 2018:831).

Tarafsızık; muhasebe bilgilerini, ilgili tarafların davranışlarını belli bir doğrultuda etkilemeyi amaçlamaksızın doğru bir biçimde sunmayı gerekli kılar (Akdoğan \& Tenker, 2010:46). "Tarafsızlık, intiyatlı davranışla desteklenir. ìhtiyatılıı, belirsizlik koşullarında yargıda bulunurken temkinli davranmaktır. İhtiyatıılık; varlık, yükümlülük, gelir veya giderlerin olduğundan yüksek veya olduğundan düşük gösterilmesine izin vermez." (Kavramsal Çerçeve). Hatasız sunum ise muhasebe işlemlerinde inmallerin olmamasını ifade etmektedir.

"Gerçeğe uygun sunum ölçüm belirsizliği seviyesinden etkilenir. Ancak bazı durumlarda ihtiyaca en uygun bilgi yüksek ölçüm belirsizliğine sahip olabilir. Bu durumda faydası en yüksek olan bilgi, ihtiyaca uygunluğu nispeten az olan ancak daha az tahmin belirsizliği içeren bilgidir." (Kavramsal Çerçeve)

Yukarıda açıklanan ihtiyaca uygunluk ve gerçeğe uygun sunum temel niteliksel özelliklerdir. Bu özelliklerin faydasını artırmayı sağlayan bazı destekleyici niteliksel özellikler de Kavramsal Çerçeve'de açıklanmıştır. Bu nitelikler aşağıdaki gibi sıralanabilir:

Karşılaştırılabilirlik: "Karşılaştıılabilirlik, kullanıııların kalemler arasındaki benzerlikleri ve farklılıkları belirleyebilmesini ve anlayabilmesini sağlar. Dolayısıyla benzer işlem ve olayların finansal etkilerinin ölçümü ve gösterimi, dönemler itibarıyla ve diğer işletmelerin ölçüm ve gösterimleriyle tutarlı olmalıdır." (BOBi FRS, md. 1.12) Bunun içinde muhasebe uygulamaları için seçilen muhasebe politikalarının birbirini izleyen dönemler itibariyle değiştirilmeden uygulanması gerekir. Ancak politikalarda değişikliğe gidilmek mecburiyetinde kalındıysa bu durum finansal tablo dipnotlarında açıklanmalıdır (Akdoğan \& Tenker, 2010:46-47).

Doğrulanabilirlik: Muhasebe bilgilerinin ön yargıdan uzak gerçek durumu yansıtacak biçimde ölçümlerinin yapılması suretiyle finansal tablolarda sunulması, işlemleri doğru temsil etmeyi sağlayacaktır (Akdoğan \& Tenker, 2010:45). Bağımsız kişilerin veya kurumların finansal tablolar üzerinden yaptıkları analiz sonuçlarının aynı çıkması muhasebe bilgilerinin doğrulanabilir olduğuna işaret etmektedir.

Zamanında Sunum: "Zamanında sunum; finansal bilginin, finansal tablo kullanıcılarının kararlarını etkileyebileceği zamanda mevcut olmasıdır." (BOBi FRS, md. 1.13)

Anlaşılabilirlik: Bilgiyi kullanan kişilerin sunulan bilgilerinden faydalanabilmesi, bilgiyi anlayabilmelerine bağlıdır. Ancak muhasebe bilgilerinin anlaşılabilir olması, bilgilerin herkes tarafından anlaşılacak ölçüde basit olması anlamına gelmez. Bu bilgilerin basitçe sunulması anlaşımasını değil, ekonomik gerçeklerin gözden kaçırılmasını doğurur. Dolayısıyla anlaşılır olma, basitlik olarak düşünülmemelidir (Akdoğan \& Tenker, 2010:43). Finansal bilgilerin anlaşılabilir olma özelliği, işletme faaliyetleri ve ekonomik faaliyetler ile muhasebe hakkında makul seviyede bilgisi olan, bu bilgileri dikkatli ve özenli bir şekilde analiz eden kullanııılar tarafından anlaşılabilecek şekilde sunulmasını gerekli kılar (BOBi FRS, md.1.11).

Literatürde yer alan çalışmalarda Kavramsal Çerçeve'de sıralanan niteliklerin yanı sıra muhasebe bilgi kalitesini artıracak diğer niteliklere de değinilmiştir. Bu nitelikler şöyle sıralanabilir:

$\checkmark$ Tahakkuk Kalitesi: Hasılat ve gider unsurlarının ait oldukları dönem, tahakkuk esasına göre belirlenir. Tahakkuk esası bir hasılat veya gider unsurunun mahiyet ve tutar itibariyle kesinleşmesidir. Bu esasa göre kesinleşen bir hasılatın tahsil edilmesi veya kesinleşen bir giderin ödenmesi beklenmeksizin kaydedilmesi gerekir (Akyol \& Küçük, 2016:111-112).

Tahakkuk esası gereği dönem içinde yapılan kredili bir satış aynı dönemde tahsil edilmemiş olsa dahi işletmenin gelir tablosunda raporlanmaktadır. Bu durum, işletmenin dönem performansının finansal tablolara yansıtılması bakımından faydalı bir yaklaşım olmakla birlikte, söz konusu satışın iade edilmesi gibi beklenmedik bir durumun meydana gelmesi halinde tahakkuk işleminin kalitesini düşürecektir (Temiz, 2018:83).

Ayrıca yöneticilerin tahakkuklara müdahale etmeleri durumunda işletmelerin gerçek performansları raporlara yansımayacaktır (Köse, 2019:34). 
$\checkmark$ Tahmin Edilebilirlik: Muhasebe bilgilerinin, gelecek dönem kârını ve hisse senedi getirilerini tahmin etmeye imkân vermesi kalite göstergesi olarak nitelendirilebilir (Köse, 2019:34-35).

$\checkmark$ Ilgililik: Muhasebe bilgileri, yatırımcıların, kredi verenlerin ve diğer ilgililerin yatırım, kredi ve benzeri kararlar alırken geçmişteki, şimdiki ve gelecekteki olayların sonuçları ile ilgili olarak değerlendirme yapmalarına, tahmin oluşturmalarına veya beklentilerini doğrulamalarına yardımcı olacak nitelikte olmalıdır (Akdoğan \& Aydın, 1987: 274).

Muhasebe bilgi kalitesi, işletme yöneticileri ile yatırımcılar arasındaki bilgi asimetrisini engelleyerek, fon sağlama imkânını kolaylaştırmak suretiyle sermaye maliyetlerini azaltması bakımından işletmeler için stratejik bir öneme sahiptir (Bharath vd. 2006: 2-3). Kaliteli muhasebe bilgilerini içeren, dolayısıyla gerçeği yansıtan, şeffaf finansal tabloların kullanımı, tasarrufların doğru kanallara yönlendirilmesini sağlayarak finansal piyasaların gelişmesine ve ekonomik büyümeye katkı sunar.

Kısaca üretim hacmindeki artış olarak tanımlanabilecek ekonomik büyüme, kalkınma düzeyi ne olursa olsun her ülke için önemlidir. Üretimi, istihdamı ve dolayısıyla milli geliri artıran doğrudan yabancı sermaye yatırımları özellikle gelişmekte olan ülkeler için ekonomik büyümede ana itici güç olarak görülmektedir (Akkaya, 2019:283). Bu yatırımların ülkeye girişini artırmada, yatırımcılara sunulan bilginin kalitesi önemli rol oynamaktadır. Nitekim Nam vd.'nin (2020)muhasebe kalitesinin, ülkeye doğrudan yabancı sermeye girişi üzerine etkisini araştırdıkları çalışmada, muhasebe kalitesinin doğrudan yabancı sermeye girişini etkilediği ve bu etkinin gelişmekte olan ülkeler için gelişmiş ülkelerden daha önemli olduğu sonucuna ulaşılmıştır.

Muhasebe bilgi kalitesinin önemi, finansal krizlerde de kendini göstermektedir. Öyle ki 2008 yılında ABD’de başlayan ve kısa sürede tüm dünyayı etkisi altına alan ekonomik krizin temel sebeplerinden biri gerçeği yansıtmayan finansal tablolardır (Can, 2010:25). Bu durum göstermektedir ki muhasebe bilgi kalitesi, finansal piyasaların daha sağ|ıkı işlemesini, dolayısıyla kriz riskinin azalmasını sağlaması bakımından oldukça önemlidir. Ayrıca kamu gelirlerinin büyük bir kısmını oluşturan vergilerin, doğru beyan edilmesine ve toplanmasına katkıda bulunarak toplum refahını artıracak hizmetler için yapılacak kamu harcamalarına daha çok kaynak aktarılmasını sağlaması bakımından da muhasebe bilgi kalitesi önem arz etmektedir.

\section{Muhasebe Bilgisinin Çevresi}

Ekonomik kalkınma ve gelişmenin, gelişmiş ekonomiler için ise sürdürülebilirliğin sağlanması kaynakların etkin kullanımına bağıdır. Etkin kaynak kullanımı ise karar vericilerin isabetli karar vermelerine, dolayısıyla karar verme süreçlerinde kullanılan bilginin kalitesine bağlıdır. Bundan dolayı muhasebe bilgi kalitesini etkileyen faktörlerin iyi tespit edilmesi ve kaliteyi azaltan faktörlere müdahale edilmesi büyük önem arz etmektedir.

Teknolojideki hızlı dönüşüme bağı olarak sosyal, ekonomik ve kültürel alanlarda yaşanan değişim ortamında işletmelerin temel amaçlarından biri olan sürekliliği sağlayabilmelerinde kaliteli bilginin önemi büyüktür. Kaliteli bilgi, işletmenin iyi performans sergilemesi, rekabet avantajı elde etmesi ve geleceği planlarken doğru kararlar alabilmesi açısından kritik öneme sahiptir (Demir, 2005:142). Ancak, muhasebe ve raporlama sisteminde değerlemede yapılan hata ve/veya hileler, muhasebe kayıtlarına yansıtılmayan finansal işlem ve faaliyetler, yaratıcı muhasebe uygulamaları vb. şirketlerin mali tablolarının ve özellikle de bilançolarının bozulmasına, gerçeği yansıtma düzeylerinin düşmesine dolayısıyla kaliteli bilgi üretilmesine mani olmaktadır (Coşkun, 2008:108).

Muhasebe bilgisi; muhasebe uygulamalarından, yasal ve politik sistemden, finansal piyasaların yapısından, vergi sisteminden ve kültürel yapıdan etkilenen çok boyutlu bir kavramdır (Gücenme Gençoğlu \& Ertan, 2012:2). Muhasebe bilgisinin çevresi olarak da ifade edilebilecek bu faktörler Şekil 1'deki gibi gösterilebilir:

Şekil 1. Muhasebe Bilgisinin Çevresi 


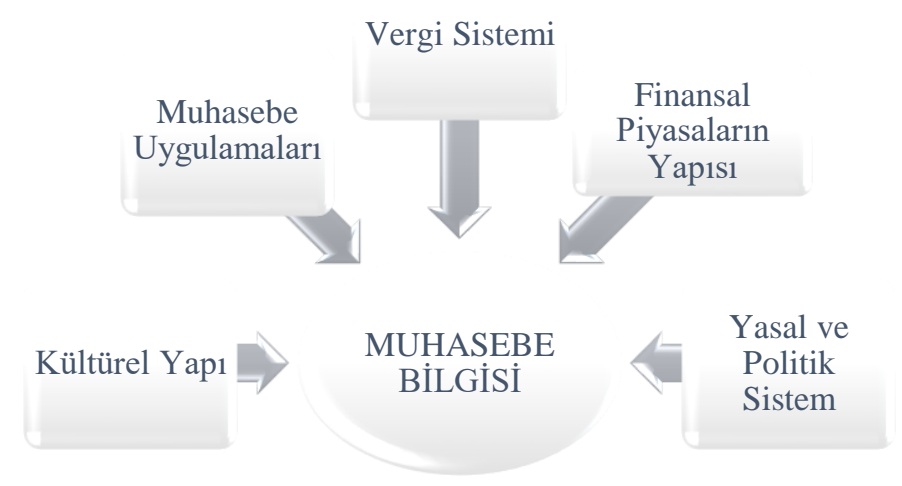

Kaynak: Şekil, tarafımızdan geliştirilmiştir.

Muhasebe bilgisi, Şekil 1'de görüldüğü gibi çok farklı ve çok boyutlu faktörlerin uyum derecesine göre artacak veya azalacaktır.

Bununla birlikte bilginin hazırlanması ve sunulması sürecinin sağlıklı bir şekilde sürdürülebilmesi için, bu süreçte davranışsal boyut göz ardı edilmemelidir (Ülkü, 2012: 48). Dolayısıyla muhasebe bilgisini oluşturan çevreye "Davranışsal Boyut" da eklenebilir.

\subsection{Muhasebe Uygulamaları}

Muhasebe uygulamaları genel olarak ilke bazlı ve kural bazlı uygulamalar olarak sınıflandırılmaktadır.

Dünyada muhasebe uygulamalarına yön veren iki önemli kuruluştan IASB (International Accounting Standards Board/Uluslararası Muhasebe Standartları Kurulu)'nun düzenlemeleri literatürde ilke bazlı olarak; FASB (Financial Accounting Standards Board/Finansal Muhasebe Standartları Kurulu)'nun uygulamaları ise kural bazlı olarak kabul edilmektedir. İlke bazlı uygulamalar prensiplerin genel hatları ile belirlendiği, koşullara göre uyarlanabilen, yoruma açık uygulamalarken, kural bazı uygulamalar yoruma kapalı, kesin hükümler içeren uygulamalardır (Kayıtmaz Balsarı \& Dalkılıç, 2007:106).

Mesleki yargıların önem kazandığı ilke bazlı yaklaşımlarda finansal tabloları hazırlayanların iyi niyetli oldukları ve hazırlanan tabloların gerçek durumu yansıttıkları kabul edilir. Kural bazlı yaklaşımlarda ise finansal tabloları hazırlayanlara mesleki yargılarını kullanacakları uygulama alternatifleri sunulmamaktadır (Barth vd, 2006:10). İlke bazlı yaklaşımın yoruma açık olması, farklı bilgi ve deneyime sahip kişilerce hazırlanan finansal tablolarda benzer işlemlerin farklı sunulmasına yol açarak finansal tabloların karşılaştırılabilirliğini zedeleyebilmektedir. Kural bazlı uygulamalarda ise esnekliğin olmaması farklı işlemlerin belirli bir formata uyarlanarak benzer işlem gibi raporlanması sonucunu doğurabilmektedir. Ayrıca kural bazlı uygulamalar, yoruma kapalı olması sebebiyle günümüzde yaşanan hızlı değişim koşullarında ihtiyaçları karşılamakta yetersiz kalabilmektedir (Gücenme Gençoğlu \& Ertan, 2012:4).

\subsection{Yasal ve Politik Sistem}

Dünya üzerindeki çağdaş hukuk sistemleri taşıdıkları ortak nitelikler bakımından Anglosakson ve Kıta Avrupası hukuk sistemi olarak iki temel gruplandırmaya tabi tutulabilir.

Ortak hukuk (Common Law) olarak da bilinen Anglosakson hukuk sisteminde kuralların yazılı olma zorunluluğu yoktur. Kamu hukuku-özel hukuk ayrımının olmadığı bu sistemde yargı birliği geçerlidir. Bu sistemde töre, asli hukuk kaynakları arasında yer alır. Vicdani bağımsızlıklarına büyük önem verilen hâkimler bu sisteminin en önemli unsurudur. Kişi ve kuruluşlar bu sistemde arzu edilmeyen davranışlardan caydııılmaya çalışılır (www.tr.wikipedia.org, 2020).

Türk hukuk sisteminin de mensubu olduğu Kıta Avrupası hukuk sisteminde ise, yazılı hukuk kuralları asli kaynak, yargı kararları yardımcı kaynak olarak nitelendirilir. Ayrıca kamu hukuku-özel hukuk ayrımının yapıldığı yargı ayrığı ilkesinin geçerli olduğu bu sistemde kişi ve kuruluşlar arzu edilen davranışların sergilenmesi doğrultusunda zorlanmaktadır (Ertan, 2011:35).

Vergi hukukunun ve şirketler hukukunun muhasebe uygulamalarına dair düzenlemeleri içermesi, yasal sistemlerin muhasebe kalitesi üzerinde etkisi olduğunun önemli bir göstergesidir (Jaggi \& Low, 2000:500). Bununla 
birlikte muhasebe kalitesinin artırılması, ilgili yasal düzenlemelerin ne kadar kabul gördüğü ve ne kadar etkin uygulandığı ile ilgilidir.

Kıta Avrupası hukuk sisteminde temel belirleyici devletken, Anglosakson hukuk sisteminde yatırımcılardır (Karabayır, 2019:54). Kuralların belirlenmesinde ve uygulanmasında devletin baskın role sahip olduğu Kıta Avrupası hukuk sisteminde muhasebe mesleğinin etkisinin zayıf olduğu görülmektedir. Ayrıca bu sistemi benimseyen ülkelerin muhasebe sistemlerinde Anglosakson hukuk sistemini benimseyen ülkelere kıyasla daha az muhasebe bilgisi raporlanarak sunulmaktadır. Bu durumun tersine, Anglosakson hukuk sistemini benimseyen ülkelerde muhasebeye ilişkin düzenlemeler ile uygulamalar muhasebe meslek örgütleri tarafından belirlenmekte ve kullanıcılar için daha fazla muhasebe bilgisi rapor halinde sunulmaktadır (Schoereder, 2005:72).

La Porta ve Lopez de Silanez'in, ülkelerin hukuk sistemlerinin finansal sistemleri üzerindeki etkisini incelemek amacıyla yaptıkları çalışmada, Anglosakson hukuk sistemine sahip ülkelerin Kıta Avrupası hukuk sistemine sahip ülkelere kıyasla daha iyi muhasebe sistemine sahip oldukları ve yatırımcıları daha fazla korudukları sonucuna ulaşılmıştır (La Porta \& Lopez de Silanez, 1998: 1121).

Politik etkilerin çok fazla olduğu Kıta Avrupası hukuk sisteminde muhasebenin rolü daha çok vergi odaklı iken, Anglosakson hukuk sisteminde bilgi verme odaklıdır (Ball vd, 2000:8).

İşleyişinde sorunlar ve aksaklıklar olan politik sistemlerde, yöneticiler ve işletme sahipleri, devletten ihale alabilmek, piyasada tekel oluşturabilmek veya daha az vergi ödemek türündeki amaçları gerçekleştirmek adına harcamalar yapabilmekte ve doğal olarak da bu harcama tutarlarını mali tablolara yansıtmaktan kaçınabilmektedirler (Soderstorm \& Sun, 2007: 691).

Chen vd.'nin (2020) Çin'de yolsuzluk kültürünün muhasebe kalitesine etkilerini incelemek amacıyla yaptıkları çalışmada, muhasebe kalitesinin, güçlü yetkililerle ilişkili ve yolsuzluğa bulaşmış yetkililerle daha güçlü bağlantılara sahip firmalar için düştüğü sonucuna ulaşıımıştır. Ayrıca çalışmada yüksek kaliteli denetçilerle çalışan ve daha iyi iç kontrole sahip olan firmaların muhasebe kalitelerinin yüksek olduğu belirtilmiştir.

Benzer bir amaçla yolsuzluk ve muhasebe kalitesi arasındaki ilişkiyi araştıran Çetenak vd.'nin (2021) aralarında Türkiye'nin de bulunduğu 11 farklı ülkenin yolsuzluk endeksleri ile bu ülkelerde faaliyet gösteren 3816 işletmenin isteğe bağlı tahakkuklarını inceledikleri çalışmada, yolsuzluk arttıkça muhasebe bilgi kalitesinin azaldığı, düştükçe muhasebe bilgi kalitesinin arttığı sonucuna ulaşımıştır.

\subsection{Finansal Piyasaların Yapısı}

Fon arz ve talebinin karşılaştığı piyasalar olan finansal piyasalar, finansal varlıkların vadelerine göre sermaye piyasası ve para piyasası olarak ikili bir ayrıma tabi tutulmaktadır. Fon intiyaçlarının ağırıklı olarak sermaye piyasalarından karşılandığı gelişmiş ekonomilerde fon arz edenler ihtiyaç duydukları bilgiye rahatlıkla erişebilmektedir. Bu durum sermayenin tabana yayılmasını ve volatilitenin azalmasını sağlayarak piyasaların gelişmesi üzerine önemli derecede etki eder. Bu piyasalarda bilgi daha çok işletmeler tarafından üretilmiş finansal tablolar aracılığıyla elde edilir. Bu durum finansal tablo hazırlayanları, muhasebe bilgilerinin daha kaliteli sunulması yönünde hareket etmeye zorlamaktadır.

Sermaye piyasası gelişmemiş ekonomilerde ise fon ihtiyacı daha çok para piyasasının temel aktörleri olan bankalar aracılığıyla karşılanır. Bu tür ekonomilerde şirketler ile bankalar arasında güçlü bir bağ vardır. Şirketlerin ihtiyaç duydukları firma bilgilerine bankalar aracılığıyla direkt ulaşılarak bilgi asimetrisi problemi önlenir. Finansmanın ağıllıklı olarak kredi yoluyla sağlandığı bu ekonomilerde intiyaç duyulan bilgilere bankalar aracılığıyla doğrudan erişilmesi, finansal tablo bilgilerine duyulan ihtiyacı azaltmaktadır. Bu durum muhasebe bilgi kalitesinin azalmasına yol açar (Sun, 2005:23-24; Gücenme Gençoğlu \& Ertan, 2012:11).

\subsection{Vergi Sistemi}

Ülkedeki muhasebe uygulamalarının vergi odaklı veya bilgi odaklı olması finansal raporlama kalitesini doğrudan etkilemektedir. Bilgi odaklı muhasebe uygulamalarının geçerli olduğu ülkelerde muhasebe kalitesinin, vergi odaklı ülkelere kıyasla daha yüksek olduğu söylenebilir.

Vergi odaklı sistemlerde, muhasebe uygulamalarına yön veren ağılıklı olarak vergi mevzuatlarıdır. Vergi mevzuatları yatırımcılar için bilgi üretmekten ziyade, hükümetler için vergi toplamak gibi politik bir amaca hizmet eder 
(Gücenme Gençoğlu \& Ertan, 2012:12). Yatırımcıların aleyhine olan bu durumun olumsuz etkileri, finansal tablolarda ticari kâr rakamı ve mali kâr rakamına ayrı ayrı yer verilmesi ile bir miktar da olsa giderilebilmektedir.

Muhasebe ve vergilemenin kesiştiği nokta vergi matrahın tespiti işlemidir. Modern vergicilikte matrah tespiti beyan usulüne dayanmaktadır (Bayraklı, 2007:76). Bu usulde vergi matrahı mükelleflerce hesaplanarak vergi dairelerine beyan edilmektedir. Vergi odaklı muhasebe uygulamalarının geçerli olduğu ülkelerde muhasebe bilgi kalitesi, vergi oranlarının yüksekliğine bağlı olarak düşebilmektedir (Durak \& Gürel, 2014:104). Vergi oranlarının yüksekliğinin doğurduğu olumsuz psikoloji ile mükellef, yasal boşlukları kullanabilmekte veya gerçek işlemleri gizlemek için yasalara aykırı fillerde bulunmak gibi etik olmayan davranışlara yönelerek gerçek dışı matrahlar beyan edebilmektedir.

Ülkelerin ticaret kanunlarında yer alan muhasebe ile ilgili düzenlemelerin daha çok bilgi odaklı, vergi kanunlarındaki düzenlemelerin ise vergi odaklı olması beklenir. Ülkemizde yürürlükte olan VUK (Vergi Usul Kanunu)'da, muhasebe kayıt ve belge düzeni, değerleme ölçüleri, matrah tespiti gibi konularda ayrıntılı düzenlemelere yer verilmişken, 1956-2011 yılları arasını kapsayan uzun bir dönem boyunca yürürlükte olan 6762 sayılı TTK (Türk Ticaret Kanunu)'da, muhasebe konusunda ayrıntılı düzenlemelere yer verilmemiştir. Bu durum ülkemizde muhasebe uygulamalarının ağırlıklı olarak vergi odaklı yürütülmesine sebep olmuştur (Gücenme Gençoğlu \& Ertan, 2012:12-13.)

2011 yılında yürürlüğe giren ve muhasebe uygulamalarında TMS (Türkiye Muhasebe Standardı) ve TFRS (Türkiye Finansal Raporlama Standardı)'ye atıfta bulunan düzenlemeler içeren, dolayısıyla işletmeleri TMS/TFRS'leri uygulamaya yönlendiren 6102 sayılı TTK ile bilgi odaklı muhasebe uygulamaları teşvik edilmektedir.

Günümüzde, Türkiye'de, işletmelerden KAYik (Kamu Yararını ilgilendiren Kuruluşlar) TMS/TFRS'yi, KAYik sayılmamakla beraber bağımsız denetime tabi olan işletmeler isteğe bağlı olarak TMS'yi veya BOBi FRS (Büyük ve Orta Boy Iş̧letmeler için Finansal Raporlama Standardı)'yi, bağımsız denetime tabi olmayan işletmeler ise MSUGT'u dikkate alarak kayıtlarını tutarlar. Bu durum göstermektedir ki bağımsız denetime tabi olan işletmelerde bilgi odaklı, diğer işletmelerde ise vergi odaklı uygulamalar geçerlidir.

\subsection{Kültürel Yapı}

Kültür, insanların toplumsal ve tarihsel gelişim süreci içinde edinerek çeşitli yollarla birbirlerine ilettikleri ve sonraki kuşaklara aktardıkları maddi ve manevi öğelerin toplamıdır (Kocacık, 2000:77). Ülkedeki kültürel yapı, o ülkedeki muhasebe uygulamalarını şekillendiren önemli etkenlerden biridir. Gray'in 1988'de ülkelerin muhasebe uygulamalarındaki farklıı̆̆ı kültürle ilişkilendirdiği araştırmasının temel dayanağını Hofstede'nin literatüre kattığı dört kültürel boyut oluşturmaktadır.

Hosftede'nin 1967-1973 yılları arasında yaptığı araştırmasında, farklı ülkelerde şubeleri olan IBM bilgisayar firmasının çalışanları katııımc olarak yer almıştır. Bu araştırmada, katııımcılar aynı firmanın çalışanları olmalarına rağmen, iş hayatında farklı değer yargılarına sahip oldukları sonucuna ulaşılmıştır. Hofstede, personelin iş hayatına bakışında dört kültürel boyutun öne çıktığını savunmuştur. Bunlar; bireysel-kolektif boyut, güç mesafesi boyutu, belirsizlikten kaçınma boyutu ve dişillik-erillik boyutudur (Hofstede, 1991:28).

Bireysel-Kolektif Boyut: Bu boyut toplumdaki insanların gruplara ne kadar bağlı olduklarını açıklamaktadır. Bireyci toplumlarda birey yalnızca kendinden ve yakın ailesinden sorumludur. Bireyler "biz" değil "ben" bilincine sahiptir. Bireyler arasındaki ilişkilerde görev önceliklidir. Kolektif kültüre sahip toplumlarda ise "biz" bilinci hâkimdir. Bireyler topluma sadakat duygusu ile bağııdır. Bireyler arasındaki ilişkilerde görev arka plandadır (Hofstede, 2011:11). Bireyci kültürlerde değerler şahısta bulunurken, kolektif kültürlerde sosyal gruplarda bulunur (Wursten \& Fadrhonc, 2012:4). Bu boyut, aynı zamanda toplumu oluşturan bireylerin birbirine bağııık derecesini ifade etmektedir. Toplumdaki kişilerin birbirleriyle olan bağ|lıkları zayıf ise bireysellik yüksektir. Aksine kolektiflik de ise bireylerin birbirlerine olan bağlıı̆ı sıkıdır (Hofstede, 1991:51).

Güç (Otorite) Mesafesi Boyutu: Otorite mesafesi, toplumdaki kurum ve organizasyonların eşit olmayan güç ve otoriteyi kabullenme derecesini ifade etmektedir (Hofstede, 1991:51). Hofstede'ye göre insanlar farklı fiziksel ve entelektüel kapasitelere sahip olduklarından eşit değillerdir. Bu eşitsizlikler zamanla toplumda güç ve zenginlikte de eşitsizliğe dönüşmüştür. Bu eşitsizlik derecesi, Hofstede tarafından geliştirilen ve 0 (düşük güç mesafesi) ile 100 (yüksek güç mesafesi) arasında değişen güç mesafesi ölçeği ile ölçülebilmektedir (Hofstede, 1983:81).

Bütün bireylerin birbirleri ile bağlantılı olması, toplum içerisindeki eşitsizliklerin en aza indirilmesi, gücün kullanımının yasal olması ve sorgulanması, herkesin eşit haklara sahip olması düşük güç mesafesinin göstergeleri iken; 
toplumun çok az bir kesiminin bağımsız olması, bireylerin sahip oldukları güce göre sınıflandırılması, güç kullanımın sorgulanmaması, güce sahip olanların ayrıcalıklı olması yüksek güç mesafesinin göstergeleridir (Hofstede, 2011:9).

Belirsizlikten Kaçınma Boyutu: Bu boyut genel olarak toplumun belirsizlik karşısında gösterdiği reaksiyon ile ilgidir. Belirsizlikten kaçınan toplumlarda, katı yasalar, kurallar ve güvenlik önlemleri ile yapılandırılmamış durumlar karşısında gelişecek olumsuzluklar en aza indirgenmeye çalışıır. Kurallara aykırı davranan kişiler toplum tarafından reddedilir (Hofstede \& McCrae, 2004: 62).

Zayıf belirsizlikten kaçınma kültür düzeyine sahip toplumlarda ise genel olarak katı yasal düzenlemelerden ziyade güçlü bir inanç sistemi hâkimdir. Bu toplumlarda insanlar daha yenilikçi ve girişimci olma eğilimindedirler (Karadağ, 2020:52).

Dişilik-Erillik Boyutu: Bu boyutta cinsiyet özellikleri üzerinden toplumsal yapıya atıfta bulunulmaktadır. Erillik; toplumda başarı, iddiacılık ve maddi başarılar elde edilmesinin öncelikli olması durumudur. Dişil toplumlar ise ilişkilerde başarıyı ve alçak gönüllülüğü ön planda tutar ve yaşam kalitesinin yüksek olmasını tercih ederler. Eril toplumlarda kurumlar performans ve başarıya dayalı olarak kurulur ve yönetilirler. Dişil toplumlar ise refah toplumlarıdır, yaşam kalitesine önem verir, güçsüzü korumaya çalışırlar (Hofstede, 1991:82).

Gray, yukarıda sıralanan dört kültürel boyutu, uluslararası muhasebe uygulamalarındaki farklıların kültürel sebepleri ile ilişkilendirmiş ve iki zıt unsuru içeren dört boyutlu bir sınıflandırma ortaya koymuştur. Gray'in sınıflandırması; profesyonelliğe karşı statükoculuk, tek düzenciliğe karşı esneklik, ihtiyatılılğa karşı iyimserlik ve gizliliğe karşı şeffaflıktır (Gray, 1988:9-11):

Türkiye'de Gray'in teorisinden yola çıkılarak, muhasebe ve kültür ilişkisini ortaya koymayı amaçlayan birçok çalışma yapılmıştır. Bu çalışmalardan biri Güvenç'in Mersin ilinde faaliyette bulunan 198 meslek mensubunun katııımcı olarak yer aldığı çalışmasıdır. Çalışmada, meslek mensuplarının profesyonellikten ve tek düzencilikten yana, ihtiyatıı̆ı̆ın ve gizliliğin hâkim olduğu bir tavrı benimsedikleri sonucuna ulaşılmıştır (Güvenç, 2005:80).

Aktaş'ın Bursa'da faaliyet gösteren 240 muhasebe meslek mensubunun katııımı ile gerçekleştirdiği çalışmasında, katılımcıların profesyonellik, esneklik ve iyimserlikten yana oldukları, şeffaflık konusunda ise kararsız kaldıkları tespit edilmiştir (Aktaş, 2008:122-123).

Durmuş ve Güneş'in, 8 farklı YMM odasından 420 YMM ile gerçekleştirdikleri anket çalışmalarında, YMM'lerin profesyonellikten yana oldukları, ihtiyatılık ile tek düzenciliği savundukları ve şeffaflı̆̆ destekledikleri sonucuna ulaşılmıştır (Durmuş \& Güneş, 2017:81).

\section{Muhasebe Bilgi Kalitesini Artıran Faktörler}

İşletmeler, başta yatırımcılar olmak üzere bilgi kullanıcılarını bilgilendirmek için belirli aralıklarla finansal durumlarını ve faaliyet durumlarını raporlar aracılığıyla açıklarlar. Bu açıklamalarda temel amaç paydaşlara geçmiş ve mevcut bilgileri değerlendirme imkânı sunarak gelecek hakkında karar almalarına yardımcı olmaktır (Kalmış \& Dalgın, 2010:115). ilgililerin kararlarında referans aldıkları raporlar başta finansal tablolar ve bunların dipnotlarıdır.

Bunların dışında, yönetim kurulu faaliyet raporu, yönetim kurulu başkanının açıklamaları, performans ölçütleri, yöneticiler ve hisse senedi sahipleri hakkında bilgiler, bağımsız denetçi raporu gibi ilgililere sunulan diğer raporlardır (Öğücü Şen, 2017:29).

Bilgi kullanıcılarının kendilerine sunulan raporları kullanarak doğru ve etkili karar almaları, raporlarda yer alan bilgilerin fayda sağlayacak nitelikte kaliteli bilgiler olmasına bağııdır. Bilgilerin tek düzen muhasebe sistemine ve muhasebe standartlarına uygun üretilmesi, işletmede etkin iç denetim ve kontrol yapılarının oluşturulup uygulanması, denetim komitesinin ve bağımsız dış denetimin etkinliği, muhasebe meslek mensuplarının sürekli eğitimi ve meslek örgütlerinin güçlü bir alt yapıya sahip olmaları sunulan bilginin kalitesini artıracak uygulamalardır.

\subsection{Tekdüzen Muhasebe Sistemine Uyum}

Benzer işletmeler tarafından, benzer niteliklere sahip olayların aynı sistem içerisinde muhasebeye yansıtılması tekdüzen muhasebe sistemini oluşturur.

26.12.1992 tarih ve 21447 (Mükerrer) sayılı Resmi Gazetede yayımlanan 1. Sıra No.lu Muhasebe Sistemi Uygulama Genel Tebliği (MSUGT) uyarınca 1 Ocak 1994 tarihinden itibaren standart tekdüzen muhasebe sistemine geçilmiştir. Tekdüzen Muhasebe Sistemi ile işletmeler, muhasebe uygulamalarında, benzer finansal işlem ve olaylara 
aynı hesap planı, muhasebe ilkeleri, muhasebe kavramları ile cevap vermeye ve muhasebe bilgilerini tek tip (tekdüzen) finansal tablo ve raporlarda sunmaya başlamışlardır (www.vergidosyasi.com, 2021).

MSUGT ile işletmenin faaliyet sonuçlarının ve mali durumunun, ilgililere açık bir şekilde gerçeğe uygun olarak yansıtılması amacıyla, temel finansal tablolar olarak nitelendirilen bilançoya ve gelir tablosuna yönelik olarak, tabloların gerek hazırlanması gerek sunulması aşamalarında dikkate alınması gereken ilkeler belirlenmiştir. Bunlar Tebliğ'de bilanço ve gelir tablosu ilkeleri başığında maddeler halinde sıralanmıştır.

Tebliğ'de ayrıca finansal raporlar hazırlanırken uyulması gereken temel kavramlar 12 adet olarak sıralanmış ve açıklanmıştır. Bu kavramlar, uluslararası geçerliği olan ve tüm dünyada muhasebe uygulamalarına yön veren ve rehber niteliği taşıyan temel esaslardır.

Temel kavramlar incelendiğinde bunların, mesleki faaliyetlerin icrasında meslek mensuplarının uygulamalarına ışık tutan, pek çok finansal konuda akla takılan sorulara ve tereddütlere cevap veren nitelik arz ettikleri görülecektir. Muhasebe uygulamalarını bu kavramlar doğrultusunda yürüten ve finansal tablolarını bu kavramlara uygun hazırlayan işletmelerde;

1. Tek bir kişi veya grubun değil tüm toplumun çıkarları gözetilir.

2. İşletme faaliyetleri, işletmenin, ortak, çalışan veya herhangi bir ilgiliden bağımsız kendine özgü bir kişiliğe sahip olduğu bilinci ile yürütülür.

3. Finansal tablolar düzenlenirken işletme faaliyetlerinin herhangi bir süreye bağı olmadan devam edeceği göz önünde bulundurulur.

4. Faaliyet sonuçları birbirini takip eden ancak birbirinden bağımsız dönemler itibariyle saptanır.

5. Finansal olay ve işlemler muhasebeye ortak bir ölçü birimi olarak ulusal para ile yansıtılır.

6. Para mevcudu, alacaklar ve maliyetinin tespit edilmesi mümkün veya uygun olmayan kalemler hariç, edinilen varlık ve hizmetler elde edilme maliyetleri ile muhasebeleştirilir.

7. Muhasebe kayıtları objektif ve usulüne uygun hazırlanan belgelere dayandırılır ve muhasebe kayıt yöntemleri seçilirken tarafsız davranılır.

8. Muhasebe politikaları birbirini izleyen dönemlerde değiştirilmeden uygulanır.

9. Finansal tablolar yeterli, açık ve anlaşılır olarak hazırlanır.

10. Illerde karşılaşılabilecek riskler göz önünde bulundurularak muhtemel gider ve zararlar için karşılık ayırılır.

11. Önemli hesap kalemlerine ve önemli mali olaylara finansal tablolarda mutlaka yer verilir.

12. İşlemlerin özleri ile biçimleri arasında farklılık oluştuğunda öze önem verilir.

Muhasebe temel kavramlarına ve finansal tablo ilkelerine uyum, üretilen bilgilerin gerçeğe ve ihtiyaca uygun, karşılaştırılabilir, anlaşılabilir, doğrulanabilir olmasını ve zamanında sunulmasını sağlayarak bilgilerin kalitesini artıracak uygulamaların başında gelmektedir.

Demir vd. tarafından Sivas SMMM Odası'na kayıtlı görevini fiilen icra eden SMMM'lerin katılımcı olarak yer aldığı ve muhasebe uygulamalarında temel kavramlara uyum düzeyini belirlemeye yönelik yapılan araştırmada katılımcılar, temel kavramların önemini ve gerekliliğini güçlü bir tonda belirtişmiş olsalar da muhasebe uygulamalarında bir bütün olarak bu kavramlara uygun hareket etme düzeylerinin "Orta Derecede Katılırım" düzeyinde olduğu bulgusuna ulaşılmıştır (Demir vd. 2020:1358-1372). Bu sonuç, muhasebe bilgilerinin kalitesinin düzeyi hakkında düşündürücüdür.

\subsection{Muhasebe Standartlarına Uyum}

Muhasebe standartları, bilgi üretiminde kullanılacak ölçütler ile bilgi sunumundaki nitelikleri belirleyerek muhasebe süreçlerinde uygulama birliği oluşturmak suretiyle muhasebe uygulamalarına yön veren ilke ve kurallar topluluğunu ifade etmektedir.

Diğer bir ifade ile muhasebe standartları, küresel olarak kullanılmak üzere oluşturulan ve muhasebe uygulamalarında yer alan sorunlu alan ve boşlukları azaltarak ve ülkeler arasındaki rekabet gücünü artırarak bilgi sunumunun kalitesini daha da artırmak için oluşturulan standartlardır (Abuda \& Rudiawarni, 2015:256). 
Ekonomide küresel boyutta yaşanan gelişmeler, ülkeler arasındaki ekonomileri birbirine bağlı ve bağımlı hale getirmiş, finansal tabloların hazırlanmasında ve sunulmasında ortak muhasebe ilkeleri paydasında buluşulması ve aynı ölçütlerin esas alınmasını zorunlu hale getirmiştir (Kocamaz, 2012:106).

Muhasebe standartları, işletmelerin finansal performanslarının karşılaştııılmasında aynı temele dayanan düzenlemelerin esas alınmasıyla daha gerçekçi sonuçlara ulaşılması, geleceğe yönelik amaçlar ile bu doğrultudaki planların tespitinde etkinliğin sağlanması ve dönemler itibariyle gerçekleşecek finansal analizler ve denetimlerde kolaylık sunması bakımından işletme yönetimine faydalı olmaktadır (Ataman Akgül \& Akay, 2003:35). Ayrıca farkı piyasalarda kote olan şirketlerin aynı standartlara göre finansal tablo düzenlemesi suretiyle sermaye maliyetinin azalması, şeffaf bilgi sayesinde piyasalara giriş ve çıkışların kolaylaşması ve dolayısıyla rekabetin artması, yatırım kaynaklarının etkin dağılımının sağlanarak ekonomik büyümenin teşvik edilmesi bakımından da toplumun geniş bir kesimine fayda sağlamaktadır (Pirgaip, 2003).

Son yıllarda muhasebe bilgi kalitesi ile muhasebe standartları arasındaki ilişkiyi incelemek amacıyla birçok çalışma yapılmış ve bu çalışmalar sonucunda muhasebe standartlarının uygulanmasıyla birlikte muhasebe kalitesinin de artmaya başladığı yönünde bulgulara ulaşılmıştır. Soderstrom ve Sun'un yaptıkları çalışmada, muhasebe standartları, ülkedeki siyasi sistem, yargı sistemi ve finansal raporlama teşviklerinin muhasebe kalitesini belirleyen faktörler olduğu ve bu faktörlerden etki düzeyi en yüksek olanın muhasebe standartları olduğu ifade edilmiştir (Soderstrom \& Sun, 2007: 695). Jun-bo ve Hai-Zhong'un yaptıkları çalışmada, muhasebe standartlarının uygulamaya başlanması ile firmaların finansal tablolarının etkin bir şekilde karşılaştırılabilir bir niteliğe kavuşacağı ve dolayısıyla bilgi ve işlem maliyetlerinin daha da azalacağı ve bu durumun hisse senedi piyasalarında olumlu bir etki doğurabileceği belirtilmiştir (Jun-bo \& HaiZhong, 2011:701). Duarte vd.'nin yaptıkları çalışmada, muhasebe standartları geliştirilmeye devam edildikçe, bu standartlara göre hazırlanan mali tabloların giderek daha güvenilir ve gerçeğe uygun olarak sunulacağının ve böylece muhasebe bilgi kalitesinin artacağının beklendiği ifade edilmiştir (Duarte vd, 2015:106).

\section{3. İç Kontrol Sisteminin Etkinliği}

iç kontrol; varlıkların korunması, finansal işlemlerle ilgili muhasebe kayıtlarının doğru ve tam olması ve güvenilir muhasebe bilgilerinin zamanında ilgili menfaat (çıkar) gruplarına ulaştırılması amacıyla işletmede uygulanan yöntemlerin bütünüdür (Usul, 2013:94).

Sağlıklı ve iyi işleyen bir iç kontrol sistemi ve yapısı ancak muhasebe bilgi sisteminin, yönetimin ihtiyaçlarına cevap verecek şekilde kurulması ile gerçekleşebilir (Türedi \& Tepegöz, 2018:144). İç kontrol sistemi sayesinde işletmenin amaçlarına ulaşması daha kolay olabilecektir.

Etkili bir iç kontrol yapısının ortaya koyduğu hedefler aşağıdaki gibi sıralanabilir (Bozkurt, 2018:129):

$\checkmark$ Gerçekten var olan işlemlerin kayda alınması

$\checkmark$ işlemlerin verilmiş yetkiye dayanarak yapılması

$\checkmark$ işlemlerin uygun bir şekilde değerlenmesi

$\checkmark$ iş̧lemlerin doğru hesaplara kaydedilmesi

$\checkmark$ işlemlerin zamanında kayda alınması

$\checkmark$ işlemlerin tablo ve raporlara gerektiği gibi yansıtılması

Muhasebe işlemlerinin sıralanan bu hedeflere uygun gerçekleştirilmesi üretilen bilginin kalitesini artıracaktır.

\section{4. İç Denetim Sisteminin Etkinliği}

İ̧ Denetçiler Enstitüsü’nün tanımına göre "iç denetim bir organizasyonun faaliyetlerine değer katmak ve geliştirmek amacıyla tasarlanmış bağımsız, objektif bir güvence ve danışmanlık faaliyetidir."

Iç denetimin danışmanlık rolü, iç denetçinin yönetimin ihtiyaç duyduğu denetimi yapmasını ifade eder. İ̧ denetçinin temel görevi, işletmenin iç kontrollerini değerlendirerek, sürekli etkin halde kalması için iyileştirme önerileri getirmektir (Uzay, 2014:121). 
iç denetim faaliyetleri ile yönetim tarafından işletme kaynaklarının etkili, ekonomik ve verimli bir şekilde kullanımı, faaliyetlerin mevzuata uygunluğu, işletme varlıklarının korunması ve iç kontrol sisteminin ürettiği bilgilerin yeterliliği ve güvenilirliği konuları değerlendirilir. İç denetim faaliyetleri her ne kadar işletme yönetimine güvence vermek ve danışmanlık yapmak için gerçekleştirilse de bu süreçte diğer bilgi kullanıcılarının da yararlanacağı veriler üretildiğinden onlara karşı da güvence ve danışmanlık hizmeti sağlamış olur (Doğan, 2016:45). Ancak iç denetim sonucunda güvenilir bir yargıya ulaşılması, iç denetçinin denetim faaliyetleri esnasında yeterince açık ve objektif değerlendirmeler yapabilmesiyle mümkün olabilmektedir. Objektifliği sağlamanın yolu ise denetim ilkelerinin önceden belirlenmesi ve belirlenen ilkelere uygun hareket edilmesinden geçmektedir (Köse, 2007: 50).

İç denetim ile bilgi üretim süreçlerinin etkin bir şekilde sürekli denetim altına alınması bilgi hatalarını ortadan kaldırarak muhasebe bilgisinin kalitesini artırabilmektedir (Özçelik, 2010: 151). Böylece iç denetim; üretilen muhasebe bilgilerin doğruluğu, güvenilirliği, saygınlığı, etik ve ahlaki değerlere uygunluğu gibi nitelikleri etkileyerek işletme içi ve işletme dışı bilgi kullanıcılarının kararlarını önemli ölçüde etkileyebilmektedir (Kurnaz vd, 2018: 164).

\subsection{Denetim Komitesinin Varlı̆̆ı}

Günümüzde, dünyanın çeşitli ülkelerinde getirilen yasal düzenlemelerle, halka açık işletmelerin denetim komitesi kurmaları tavsiye edilmekte veya zorunlu kılınmaktadır. Türkiye'de ise SPK (Sermaye Piyasası Kurulu) ile hisse senetleri borsada işlem gören şirketlerin, 2003 yılından itibaren denetim komitesi kurmaları zorunlu hale getirilmiştir.

SPK'ya göre "Denetimden sorumlu komite; ortaklığın muhasebe sisteminin, finansal bilgilerin kamuya açıklanmasının, bağımsız denetiminin ve iç kontrol sisteminin işleyişinin ve etkinliğinin gözetimini yapar. Bağımsız denetim kuruluşunun seçimi, bağımsız denetim sözleşmelerinin hazırlanarak bağımsız denetim sürecinin başlatılması ve bağımsız denetim kuruluşunun her aşamadaki çalışmaları denetimden sorumlu komitenin gözetiminde gerçekleştirilir." (Sermaye Piyasasında Bağımsız Denetim Standartları Hakkında Tebliğ, Seri: X, No: 22, md. 25/2)

Denetim komitesinin amaçları şöyle sıralanabilir (Ehab \& Mostaque, 2005:39):

$\checkmark$ Güçlü bir kurum kültürünün oluşturulması

$\checkmark$ Kaliteli finansal raporlama için gereken kontrollerin yapılması

$\checkmark$ iç kontrol sisteminin kurulması

$\checkmark$ Bağımsız denetçiler ile iç denetçiler arasında işbirliğinin geliştirerek denetim sürecinin sağlıklı yürütülmesinin sağlanması

$\checkmark$ işletme yönetiminin gerek bağımsız denetçilere gerekse iç denetçilere hesap verebilmesinin sağlanması

Sıralanan bu amaçların gerçekleştirilmesiyle denetim komitesi, finansal raporlama sürecini takip etmek, muhtemel hata ve hilelerin önüne geçmek, işletme başarısızıklarını engellemek, iç ve dış denetim faaliyetlerini gözlemlemek gibi fonksiyonları yerine getirerek şirket ortaklarının çıkarlarını koruyan kaliteli muhasebe bilgilerinin sunumunda önemli görevler üstlenmektedir.

\subsection{Bağımsız Dış Denetim}

"Bağımsız denetim; bir işletmenin ekonomik faaliyetlerinin yansıtıldığı finansal tablo ve diğer finansal bilgilerin önceden belirlenmiş ölçütlere uygunluğu ve doğruluğu konusunda kullanıcılara makul bir güvence sağlamak için yeterli ve uygun bağımsız denetim kanıtları ile bağımsız denetim standartlarında öngörülen gerekli bütün bağımsız denetim tekniklerinin uygulanarak, defter, kayıt ve belgeler üzerinden değerlendirilmesi ve sonuçlarının bir rapora bağlanmasıdır." (Kardeş Selimoğlu, 2014:5)

Kaliteli bir bağımsız denetim, denetçinin, denetlediği firmanın mali tablolarıyla ilgili doğru denetim görüşünü uygun bir denetim riski seviyesinde vermesidir. Bu açıdan denetim kalitesi, denetim görüşünün gerekli kanıtlarla ve objektif yargılarla desteklenerek sunulması şeklinde tanımlanmaktadır (Durukan \& Kapucugil ikiz, 2007:37). Kaliteli bir denetim süreci ancak denetçinin, müşteri işletmenin muhasebe sistemindeki problemi doğru tespit etmesi ve bu problemi ifşa etmeye-bildirmeye istekli olması ile sağlanabilir (Esendemir, 2011:56). Ayrıca denetimin kaliteli olması, denetçinin denetim ve kalite kontrol standartlarına, mesleki etik kurallara ve yasalara hâkimiyetine ve bunlara uygun davranmasına bağııdır (Altıntaş, 2007:80). Denetçinin denetim için harcadığı zaman ve çaba denetim kalitesinin bir ölçütüdür. Denetim faaliyetleri için ne kadar çok zaman ve çaba harcanırsa, denetim görüşü de o kadar kaliteli hazırlanır (Carcello vd, 2002:381). 
Bağımsız denetim vasıtasıyla muhasebe bilgilerinin yer aldığı finansal tabloların kalitesi hakkında işletme paydaşlarına güvence sunulmaktadır. Bu bağlamda, bağımsız denetimin muhasebe bilgilerinin kalitesini artırmaya yönelik işlevleri aşă̆ıdaki gibi sıralanabilir (Güredin, 2014: 25-26):

$\checkmark$ Muhasebe işlemlerinde yapılan maddi hataları ortaya çıkararak gelir ve giderlerin gerçeğe uygun şekilde gösterilmesine yardımcı olmak,

$\checkmark$ Işletmenin kârlılı̆ı, faaliyetlerinin verimliliği ve finansal durumu hakkında güvenilir bilgiler sağlamak,

$\checkmark$ Finansal tablolar temelinde hazırlanan vergi beyannamelerinin güvenini artırmak.

Bağımsız denetim, gerçeğe uygun, güvenilir bilgilerin finansal tablolarda yer almasını sağlaması bakımından muhasebe kalitesini artıran bir uygulama olarak değerlendirilebilir.

\subsection{Meslek Mensubunun Eğitimi}

Muhasebe meslek mensupları, işletmelerin faaliyetlerini güvenilir bir şekilde belgelerine dayalı olarak kaydetmek, bunları değerlendirmek suretiyle işletmenin gerçek durumunu ilgili kesimlere yansı bir şekilde sunmak ve bu tablolarda yer alan bilgileri analiz edip yorumlamak gibi görevleri yerine getirmekte ve bu görevlerinden dolayı da finansal piyasalarda önemli sorumluklar üstlenmektedirler.

Günümüzde küresel işletmelerin gelişmesi, giderek artan işlem çeşitliliği, dijital gelişmeler, finansal piyasalarda önemli sorumlulukları bulunan muhasebe meslek mensuplarının güncel gelişmeleri takip etmelerini gerekli kılmaktadır (Durmuş \& Aytulun, 2016:111-113; Tükenmez \& Kutay, 1998:448). Bu ise meslek mensuplarının sürekli eğitimi ile mümkündür.

Uluslararası alanda IFAC(International Federation of Accunting-Uluslararası Muhasebeciler Federasyonu)'nun bünyesinde faaliyette bulunan IAESB (International Accounting Education Standart Board/Uluslararası Muhasebe Eğitim Standartları Kurulu), giderek artan değişimler karşısında mesleki yetkinliğin sürdürülebilmesi için meslek mensuplarının değişime ayak uydurmalarını sağlayacak bilgi, beceri ve mesleki değerlerin temelini oluşturmak amacıyla, muhasebe eğitimi için teknik yetenekler, profesyonel yetenekler, değerler, etik ve davranışlar hakkında standartlar oluşturmaktadır (Can \& Demirci, 2016:320; Kaya, 1999: 94-95).

Ülkemizde ise 1994 yılından beri IFAC üyesi olan TÜRMOB (Türkiye Serbest Muhasebeci Mali Müşavirler ve Yeminli Mali Müşavirler Odaları Birliği), muhasebe mesleğinin kalitesini arttırmaya yönelik faaliyetlerde bulunmaktadır. TÜRMOB mesleki bilgi ve becerilerin geliştirilmesi için TMUD (Türkiye Muhasebe Uzmanları Derneği) ve TESMER (Temel Eğitim ve Staj Merkezi) gibi kuruluşlarla işbirliği halinde mesleğe dair eğitim faaliyetlerini sürdürmektedir. Özellikle TESMER muhasebe meslek mensuplarının ve adaylarının eğitim intiyaçlarını karşılama konusunda etkin olarak çalışan bir kurumdur (İ̧̧üden, 2007:139).

Bu türden kurumların sundukları gönüllü veya zorunlu eğitim programları sayesinde hem meslek mensuplarının hem de adaylarının teorik ve uygulamaya dönük muhasebe bilgi düzeyleri artmakta, yasal ve ekonomik gelişmeleri takip edebilmektedirler. Bu durum ise muhasebe bilgi kalitesini olumlu etkilemektedir.

Meslek mensuplarının genel olarak mesleği yorucu ve yıpratıcı olarak değerlendirmelerine; mükellefle olan iliş̧kilerde sorunlarla karşılaşmalarına; mükelleflerin meslek mensupları üzerinde yaptıım gücüne sahip olduklarını ve mesleğe değer vermediklerini düşünmelerine (Durmuş \& Sekizsu, 2017:436) rağmen muhasebe bilgi kalitesinin en önemli aktörü olan bu uzmanların eğitiminin önemi tartışımaz bir gerçektir. Zira Newton "Daha ilerisini gördüysem, devlerin omuzlarında durmaktandır" demiştir. Her nesil, önceki nesillerden öğrenir ve öğrendiklerini büyüklerinin insan sermayesi üzerine inşa eder. Eğitimin etkisi kaçınılmazdır, ancak doğru şekilde tahsis edilir ve uygulanırsa (Yılmaz, 2019:147).

\subsection{Muhasebe Meslek Kuruluşlarının Altyapısı}

Muhasebe meslek örgütleri, geliştirilen muhasebe uygulamaları konusunda yetkinliğin sağlanması için gerekli eğitimleri sunarak muhasebe kalitesinin korunması yönünde önemli sorumluluklar üstlenmektedirler (Durak \& Gürel, 2014:102). Güçlü meslek örgütlerinin bulunduğu ülkelerde bu örgütler, muhasebe uygulamalarının geliştirilmesinde aktif rol oynamakta ve muhasebe kalitesinin artmasını sağlamaktadır (Goldberg \& Godwin, 1997:99). 
Muhasebe uygulamalarına dair yapılan düzenlemelere yön vermenin, meslek mensubunun eğitiminde sorumluluklar üstlenmenin yanı sıra muhasebe meslek örgütleri, yayınlanmış meslek kararlarının ve etik değerlerin uygulanmasının sağlanması bakımından da önemli roller üstlenmektedir. Muhasebe mesleğinin ekonomik, bilimsel ve kültürel yönden gelişmiş ülkelerde en saygın meslekler arasında yer almasında meslek örgütlerinin çok önemli bir rolü vardır (Selek, 1995:340).

Ülkemizde 3568 sayılı Meslek Yasası ile düzenlenen mesleki örgütler, serbest muhasebeci malî müşavirler, yeminli malî müşavirler odaları ile bu odaların tamamının katılımı ile oluşan ve kamu kurumu niteliğindeki bir meslek kuruluşu olan TÜRMOB'dur. Bu mesleki örgütlerin amacı “...meslek mensuplarının ihtiyaçlarını karşılamak, meslekî faaliyetlerini kolaylaştırmak, bu mesleklerin genel menfaatlere uygun olarak gelişmesini sağlamak, meslek mensuplarının birbirleriyle ve iş sahipleri ile olan ilişkilerinde dürüstlüğü ve güveni hâkim kılmak üzere meslek disiplini ve ahlakını korumak" ifadeleri ile açıklanmıştır (3568 sayılı Kanun, md.14)

Mesleki örgütlenmenin yirminci yılında muhasebe mesleğinin ve mesleki örgütlenmenin değerlendirildiği bir çalışmada, mesleğin güçlü bir örgütsel yapıya kavuştuğu, mesleki saygınlığın yükseldiği, muhasebe uygulamalarının kalitesinin arttığı yönünde tespitlerde bulunulmuştur (Güvemli, 2009:16).

\section{Muhasebe Bilgi Kalitesini Azaltan Faktörler}

Elbette muhasebe bilgi kalitesini artıran faktörlerde yaşanan olumsuzluklar ve/veya o faktörlere uyum düzeyinin düşmesi muhasebe bilgi kalitesinin azalmasına yol açacaktır. Yine de bu başlık altında bilgi kalitesini azaltan gelişmelere, bu gelişmeler sonucunda alınan tedbirlere ve muhasebe bilgi kalitesini azaltan bazı faktörlere yer verilmiştir.

2001 yılı ve sonrasında yaşanan muhasebe skandalları finansal piyasalarda büyük yankı ve kuşku uyandırmıştır. Bu skandalları doğuran gelişmeleri ve sebepleri belirlemek amacıyla yapılan birçok araştırmada işletme yöneticilerinin, yönetim kurulu üyelerinin ve iç denetçilerin, sorumluluklarını gereği gibi yerine getirmedikleri; finansal raporlamada yanlı davranarak hata ve hileye başvurdukları ve bağımsı denetim firmalarının ise etik dışı bu davranışlara göz yumdukları belirlenmiştir.

Yaşanan bu skandallar bir taraftan yatırımcıları büyük zarara uğratırken diğer taraftan ülke ekonomilerinde büyük kayıplara yol açmış ve denetim alanında daha sıkı yasal düzenlemelere duyulan ihtiyacı gündeme getirmiştir. Bu ihtiyaçtan hareketle finansal tablolarda şeffaflı̆ın tesisi ve yatırımcıların güveninin yeniden kazanılması amacıyla 2002 yılında, ABD'de Sarbanes- Oxley Kanunu (SOX) yürürlüğe konmuştur.

SOX tipi düzenlemeler daha sonra 2002 yılında Kanada, Almanya ve Güney Afrika'da 2003 yılında Fransa'da, 2004 yılında Avustralya'da, 2005 yılında Hindistan'da, 2006 yılında Japonya ve Italya'da yürürlüğe girmiştir (www.wikipedia.org, 2021).

Türkiye'de ise 2003 yılında SPK tarafından düzenlenen bağımsız denetime dair bir tebliğ ile bu alanda SOX'a benzer bazı yeni düzenlemelere gidilmiştir. 2011 yılına gelindiğinde denetim alanında kural belirleyici tek otorite olarak faaliyet yürütmek üzere KGK kurulmuş ve "bağımsız denetçileri ve bağımsız denetim kuruluşlarını yetkilendirmek, bağımsız denetim alanında kamu gözetimi yapmak ve böylece bağımsı denetimde uygulama birliğini, gerekli güveni ve kaliteyi sağlamak ve Uluslararası Denetim Standartları'yla uyumlu Türkiye Denetim Standartları'nı oluşturmak ve yayımlamak" gibi konularda görevlendirilmiştir (www.kgk.gov.tr, 2021).

Muhasebe bilgilerinin gerçeği yansıtmayacak şekilde finansal tablolarda raporlanmasının yol açtığı skandallar göstermektedir ki, belli bir grubun çıkarına hizmet eden etik dışı davranışları, yetersiz iç kontrolü, yetersiz iç ve dış denetimi bertaraf edecek mekanizmalara ihtiyaç duyulmaktadır.

Kalitesiz muhasebe bilgileri, geniş bir yelpazeye yayılmış olan muhasebe bilgi kullanıcılarının kararlarını olumsuz etkiyerek ülke ekonomilerini zarara uğratmakta ve küresel piyasalara sirayet edebilecek ekonomik krizlerin sebebi olabilmektedir.

Muhasebe bilgi üretim sürecinde; muhasebenin temel kavram ve ilkelerine, muhasebe standartlarına ve ilgili kanun, tebliğ ve yönetmelik hükümlerine uyulmaması durumunda muhasebe bilgilerinin kalitesinde düşüşler yaşanmakta ve bu durum bilgi kullanıcılarının kararlarını olumsuz etkilemektedir (Demir \& Arslan, 2020:903).

\subsection{Yetersiz İç ve Dış Denetim}


Yetersiz iç ve dış denetim, muhasebe işlemlerinde ve finansal tablolarda yapılan hata ve hilelerin tespit edilmemesine ve sonuçta ilgililere sunulan raporların doğruluğu ve güvenirliliği hususunda ciddi sorunlara sebep olur. Hata ve hileyi bir birinden ayıran temel belirleyici fark, muhasebe uygulamasında kasıt unsurunun olup olmadığıdır. Kasıtlı olarak/bir amaç için yapılan düzensizlikler hile; kasıtsız olarak, bilmeden veya dikkatsizlikten kaynaklanan düzensizlikler ise hata olarak tanımlanmaktadır.

Özellikle büyük işletmelerde, işlemlerin çokluğu ve karmaşık bir yapı sergilemesi söz konusudur. Bu durum, muhasebe görevini icra eden personelin dikkatsizliği, tecrübesizliği, bilgisizliği ve yanılması gibi sebeplerle birleşince hatanın olması da kaçınılmaz hal almaktadır (Durmuş \& Taş, 2008:133).

Hatanın aksine muhasebe hilesinde ise, çıkar sağlama amacıyla kayıt ve belgelerin bilinçli olarak tahrip edilmesi söz konusudur. Hile, bizzat yanlış beyanda bulunarak yapılabileceği gibi yasal veya etik olmayan bir olaya sessiz kalmak da hileye sebebiyet vermektedir (Özçelik vd, 2017:201).

Muhasebe kayıt düzeninde ve bunun doğal sonucu olarak finansal tablolarda yapılan manipülatif uygulamalar elbette bir kesime fayda sağlayacaktır. Ancak işletmenin büyüklüğü ve yaygınlığı ölçüsünde başta devlet olarak kredi kurumaları, yatırımcılar gibi diğer birçok kesime zarar verecektir (Bozkurt, 2009:165). Dolayısıyla muhasebe uygulamalarının muhasebe temel kavram ve ilkeler temelinde ve özellikle de sosyal sorunluluk kavramında yer alan düzenlemeler çerçevesinde yürütülmesinin önemi ortadadır.

Muhasebe hataları, muhasebe kayıtlarında daha çok kendini gösterirken muhasebe hileleri ise ağırlıklı olarak belgeler üzerinde ve bir amaç dâhilinde isteyerek yapılmaktadır. Dolayısıyla hilelerin muhasebe sistemi içerisinde, kayıtlardan hareketle ortaya çıkarılması mümkün değildir. Mali tabloların güvenilirliğini zedeleyen hataları ve özellikle de hileleri tespit etmek ve bunları azaltmak veya ortadan kaldırmak için etkili bir iç ve dış denetim gereklidir (Hatunoğlu vd, 2012:176-177).

Finansal raporların kalitesini artırmak suretiyle, işletme yönetimi ile yatırımcılar arasındaki bilgi asimetrisini azaltarak finansal piyasaların sağlıklı işlemesi üzerinde önemli bir yeri olan denetim faaliyetleri, kaliteli yapıldığı sürece kendinden beklenen fonksiyonları yerine getirebilmektedir. Eğer denetçi yeterince bağımsız değilse ve topladığı denetim kanıtları yeterli değilse denetim raporlarında yer alan görüşlerin doğruluğundan ve güvenilirliğinden bahsedilemez. Bu açıdan etkin olmayan veya yetersiz olan iç ve dış denetim ile muhasebe hata ve hilelerin tespitinde başarısız olunacağından, bilginin kalitesi de azalacaktır.

\subsection{Yasalardaki Eksiklik ve Esneklikler}

Işletme yönetimi, yasal esnekliklerden faydalanarak, yatırımcıları, sermayedarları, kredi kurumlarını ve diğer finansal tablo kullanıcılarını yanıltmak ve aldatmak amacıyla doğru ve uygun olmayan muhasebe tekniklerini, yanlış kayıt ve sınıflandırma uygulamalarını kullanma yoluna gidebilmektedir. Muhasebe uygulamalarında, hile içermeyen, yasalardaki esnekliklerden veya boşluklardan yararlanmaya yönelik faaliyetler ise yaratıcı muhasebe olarak adlandırıır (Aygün, 2013: 50-51).

Günümüzde finansal tabloların gerçeğe uygunluğu ve güvenirliliği işletme paydaşları için oldukça önemli bir konudur. Ancak finansal tablolar, yaratıcı muhasebe uygulamalarıyla muhasebe kayıtlarına yapılan bazı müdahaleler sonucunda doğruluktan ve gerçeklikten uzaklaşabilmektedir. Bu uygulamalara, genellikle büyük işletmelerde kârın olduğundan fazla gösterilmesi, küçük işletmelerde ise tam tersine kârın olduğundan az gösterilmesi için başvurulmaktadır (Stowoly \& Breton, 2000: 44).

Yasal sistemler, işletmeleri muhasebe standartlarını uygulamaya zorlayarak ve yönetici ve denetçilerin faaliyetlerinin kontrol edilmesini sağlayarak muhasebe bilgi kalitesini doğrudan etkilemektedir. IAS/IFRS'leri oluşturan ve yayınlayan kuruluş olan IASB, standartların uygulanmasını sağlama konusunda taraflara karşı herhangi bir yaptırım gücüne sahip değildir. Aynı şekilde KGK'nın da standartların uygulanmasını sağlama konusunda herhangi bir yaptırım gücü bulunmamaktadır.

Net kurallar içermeyen, ilke bazlı bu standartlardaki esneklikler, kural koyucu tarafından, işletmelerin değişime hızlıca cevap vermelerine ve kendi iç dinamikleri doğrultusunda muhasebe süreçlerini rahatça takip edebilmelerine imkân tanımak için sağlanmış olsa da, bu durum bazen işletme yönetimi tarafından, menfi amaçlarla finansal durumu olduğundan farklı göstermek için kullanılabilmektedir. 
Yasal yaptırımların caydırıcı olduğu ülkelerde yatırımcılar, bilgiyi sunanların bilgi asimetrisini doğuran etik dışı davranışlardan kaçınacakları konusunda kendilerini güvende hissedeceklerdir. Ancak yasal düzenlemelerin bu konuda yetersiz kaldığı noktada, yatırımcılar nezdinde daha yoğun bir şekilde firma bazında sunulan bilginin kalitesi değerlendirilecektir. Nitekim Anagnostopoulou'nun (2021) yasal düzenlemelerin ve firma düzeyinde muhasebe kalitesinin bir ülkedeki yatırım verimliliğine etkisinin ne ölçüde farklıık gösterdiğini incelediği çalışmada, yasal düzenlemelerin bilgi asimetrisini azaltmada yetersiz kaldığı ülkelerde bu işlevi yerine getirmek ve verimli yatırımı teşvik etmek için firmaya özgü muhasebe kalitesine daha fazla ihtiyaç olduğu sonucuna ulaşılmıştır.

\subsection{Etik Problemlerin Varlığı ve Yasal Olmayan Talepler}

Muhasebe meslek etiği; yasalara uygun şekilde faaliyette bulunulmasını, toplumun değer yargılarının dikkate alınarak tarafsız ve güvenilir bilgilerin üretilip sunulmasını, meslek mensubunun mesleki faaliyetlerde bağımsız hareket edebilmesini ve dürüstlüğünü ifade etmektedir (Karaman, 2015: 31).

Başka bir ifade ile muhasebe meslek etiği, muhasebe için geçerli olan ahlaki değerler ve düşüncelerdir. Özellikle muhasebe mesleğindeki etik dışı davranışların birçok kesimi etkileyen ve büyük zararlara yol açan sonuçları, meslek etiğinin öneminin altını çizmektedir. Etik dışı davranışlar kamu güveninin kaybedilmesine yol açarak işletmeleri iflasa kadar götürebilecek yatırım ve tasarruf kaybıyla karşı karşıya bırakabilir. Bu durum göstermektedir ki iş dünyasındaki etik olmayan davranışlar, sadece ahlaki problemler doğurmakla kalmayıp ekonomiye de zarar vermektedir. Dolayısıyla, muhasebe işlemlerinin tüm ilgililerin yararına olacak şekilde güven veren, etik bir çerçevede yapılması ciddi derecede önem taşımaktadır (Ezeani vd, 2012:2-3).

Yöneticiler, büyüme ve hasılat hedeflerinin baskısı altında kârı en yüksek seviyeye çıkarmak, kârdaki dalgalanmayı azaltmak ve sektörde başarılı bir yönetici olarak tanınmak amacıyla, kendi menfaatleri doğrultusunda finansal bilgileri gerçeğe uygun sunmayabilirler (Balıkçı, 2016:25; Türk ve Aslan, 2017:106). Ayrıca zimmetlerin gizlenmesi, ortaklarının birbirlerini aldatma isteği, daha az kâr dağıtma isteği, yolsuzlukların gizlenmesi, hak edilmeyen teşviklerden yararlanma isteği ve vergi kaçırma isteği de bu konuda teşvik edici olabilir (MHUD, 2004:151).

Bunların dışında, devletin vergi gelirlerini artırdığı, mükelleflerin vergi uyumunun yükselmesine katkı sağladığı, devlet-mükellef barışını sağlamayı amaçladığı vb. yönünde olumlu görüşlere rağmen (Demir \& Eker, 2018: 247) vergi affı beklentisi, vergi oranlarının yüksekliği ve bürokratik işlemlerin çok olduğu yönündeki düşünceler kayıt dışı ekonomiye ve vergi kaçakçılığına sebebiyet verebilmektedir. Daha da önemlisi vergi inceleme ve denetimlerinin yetersiz olması, bu yöndeki uygulamaların artmasına da zemin hazırlamakta ve muhasebe uygulamalarında mevzuata aykırılıklara, temel kavramlardan ve etik ilkelerden sapmalara yol açabilmektedir. Bu durum, elbette üretilen muhasebe bilgisinin kalitesini olumsuz yönde etkileyecektir ve etkilemektedir.

Muhasebe bilgileri üretilirken meslek etiği açısından dikkate alınacak bazı ilkeler bulunmaktadır. Bu ilkeler aşağıdaki gibi sıralanabilir (Alkan, 2013:103):

$\checkmark$ Muhasebe bilgi üretim ve sunumunda, tüm ilgili taraflara eşit yaklaşım içinde olmak

$\checkmark$ Finansal raporları yanlış yorumlamaya yol açmayacak açıklıkta, doğrulukta ve netlikte hazırlamak

$\checkmark$ Muhasebe verilerini özel çıkarlar için kullanmamak

$\checkmark$ Muhasebe bilgi üretim ve sunumunda gerçeği yansıtmak

Üstte yer alan bu ilkeler, psikolojik ve ekonomik temelli bazı faktörler sebebiyle meslek mensuplarınca dikkate alınmayabilmektedir. Bu faktörler aşağıdaki gibi sıralanabilir (Demir ve Arslan, 2020:906-908):

$\checkmark$ Mükellef baskısı yaşamak

$\checkmark$ Müşteri kaybetme korkusu yaşamak

$\checkmark$ Meslektaşların yanlış uygulamalarından etkilenmek

$\checkmark$ Mali tabloların manipüle edilmesi talebiyle karşılaşmak

$\checkmark$ Daha az vergi beyan edilmesi talebiyle karşılaşmak

$\checkmark$ Muhasebecilik hizmetinin belirlenen asgari ücret tarifesinin altında verilmesine zorlanmak

Bu faktörlerin varlığından dolayı meslek mensuplarında oluşan psikolojik baskı üretilen muhasebe bilgisinin kalitesini de olumsuz yönde etkilemektedir.

Muhasebenin temel kavramlarından olan sosyal sorumluluğun muhasebe meslek mensubuna getirdiği yükümlülük bağımsız davranmayı gerekli kılmaktadır. Meslek mensubu sadece hizmet sunduğu firmaya karşı değil bütün kamuoyuna karşı sorumludur (Ayboğa, 2003:331). Diğer birçok meslekte, mesleki sorumluluğun yerine getirilmemesinin 
doğurduğu sonuçlardan sınırlı bir kesim etkilenirken, muhasebenin ürettiği bilgilerin niteliğinden bütün toplum etkilenebilmektedir.

Sadece sayısal veriler kullanılarak karar alınan geleneksel muhasebe anlayışında insanların rasyonel davranacağı kabul edilmektedir. Ancak insanların psikolojik yapısı, motivasyonu, yetiştiği kültürel yapı, sahip olduğu değerler, siyasi görüşleri ve dini inançları hem bilgi üretilirken hem de kullanılırken karar almada etkin rol oynamaktadır. Zaman kısıtı, sorumluluğun yüksekliği ve sosyo-psikolojik çevresel faktörlerin etkisi altında insan, beklenenin aksine rasyonel değil, irrasyonel davranışlar sergilemektedir.

\section{Sonuç}

Uluslararası yatırım ve ticaretin artmasıyla birlikte günümüzde muhasebenin işlevi sadece, işletmelerin para ile ifade edilen faaliyetlerinin takibi ile sınırlı kalmamakta, muhasebe sistemleri bilgi kullanıcılarının ihtiyaç duyduğu güvenilir bilgiyi sunmak için kontrol ve denetim işlevini de yerine getirecek şekilde dizayn edilmektedir. Bu bakımdan muhasebenin ekonomide üstlendiği fonksiyon her geçen gün çeşitlenmekte ve önemi de artmaktadır.

Muhasebe sisteminde üretilen bilgiler, gerek işletme içi gerekse işletme dışı bilgi kullanıııları tarafından karar alma süreçlerinde başvurulan önemli veriler olduğundan, alınan karaların doğru ve etkili olması bilgilerin fayda sağlayacak nitelikte kaliteli olmasına bağlıdır. Muhasebe bilgilerinin, gerçeğe uygun, intiyaca uygun, karşılaştırılabilir, doğrulanabilir, anlaşılabilir bir şekilde ve ilgililerin ihtiyaç duyduğu zamanda sunulması, kullanııılar için bilgiyi kaliteli hale getirmektedir.

Parayla ölçülebilen mali nitelikteki olaylarla ilgilenen muhasebe sisteminde sayısal verilere daha çok önem atfedilse de bilgiyi üreten muhasebe meslek mensuplarının aynı sayısal verileri kullanmış olsalar bile farklı mesleki yargılarla farklı çıktılara ulaşmaları, muhasebede sadece nicel unsurların değil nitel unsurların da önemli olduğunun göstergesidir. Bu durum muhasebe meslek mensubunun bilgi kalitesi üzerindeki rolüne ve mesleki yargısının önemine işaret etmektedir.

Geniş bir kitleye hitap eden bilgiler ürettiklerinden, topluma karşı sorumlulukları, diğer birçok meslekle kıyaslanamayacak kadar fazla olan muhasebe meslek mensuplarının, sorumluluklarını gereği gibi yerine getirilmemelerinin sonuçları toplumun büyük bir kesimini olumsuz etkileyecek finansal krizlere yol açacak kadar ağıdır. Bundan dolayı muhasebe meslek mensuplarının ürettikleri bilgilerin kalitesini azaltacak uygulamaların tespit edilerek bu uygulamaların etkisini yok etmeye yönelik müdahalelerde bulunulması oldukça önemlidir.

Muhasebe bilgi kalitesi, ülkedeki muhasebe uygulamalarının ilke bazlı veya kural bazlı oluşuna göre ya da bilgi odaklı veya vergi odaklı oluşuna göre farklı düzeylerde gerçekleşmektedir. Ayrıca ülkenin mensup olduğu hukuk sistemi, sermaye piyasasının gelişmişlik durumu ve ülkedeki hâkim kültürel yapı muhasebe bilgilerinin kalite düzeyini şekillendirmektedir.

Muhasebe bilgi kalitesi; tek düzen muhasebe sistemi ve muhasebe standartlarına uyum, iç kontrol, iç denetim ve bağımsız denetim faaliyetlerinin etkinliği, denetim komitesinin varlı̆̆ı, meslek mensubunun yeterli eğitim düzeyine sahip olması, meslek kuruluşlarının güçlü bir alt yapısının olması gibi faktörlere bağlı olarak artmaktayken, iç ve dış denetimin yetersizliği, yasal eksiklik ve esneklikler, etik problemler ve yasal olmayan talepler sonucunda azalmaktadır.

\section{Kaynakça}

Abuda, I.R. and Rudiawarni, F.A. (2015). The impacts of IFRS adoption financial statement quality for firms listed in indonesia stock exchange. Global Journal of Business and Social Science Review 3(1), 255-233.

Akdoğan, N. \& Aydın, H. (1987). Muhasebe teorileri. Ankara: Gazi Üniversitesi Yayınları No: 98.

Akdoğan, N. \& Tenker, N. (2010). Finansal tablolar ve mali analiz teknikleri. Ankara: Gazi Kitabevi.

Akkaya, M. (2019). Gelişen piyasalarda doğrudan yabancı sermaye yatırımı, ekonomik özgürlük ve ekonomik büyüme ilişkisi. TESAM Akademi Dergisi, 6(1), 283-303. https://doi.org/10.30626/tesamakademi.528021

Aktaş, M. (2008). Bursa ili muhasebe meslek mensuplarının muhasebe-kültür değerlerinin araştırılması. (Yayımlanmamış yüksek lisans tezi). Sakarya Üniversitesi.

Akyol, M.E. \& Küçük, M. (2016). Vergi ve muhasebe uygulamaları. Ankara: Yaklaşım Yayıncılık. 
Alkan, A.T. (2013). Muhasebe mesleğinin standartlaşma süreci. Konya: Çizgi Kitabevi.

Alkan, B.Ş. (2018). Muhasebe teorisi ve uygulamaları açısından muhasebe bilgisinin niteliksel özellikleri. Muhasebe Bilim Dünyası Dergisi, 20, 819-837.

Altıntaş, T. (2007). Halka açık şirketlerin bağımsız denetiminin kalitesinin algılanmasına ilişkin bir araştırma. (Yayınlanmamış Doktora Tezi). İstanbul Üniversitesi.

Anagnostopoulou, S. C. (2021). Accounting quality, Investment efficiency, and the country-level strength of institutional enforcement. Investment Efficiency, and the Country-Level Strength of Institutional Enforcement March, 1-47. http://dx.doi.org/10.2139/ssrn.3796797

Ataman Akgül, B. \& Akay, H. (2003). Uluslararası muhasebe standartları ve Türkiye'de uygulama etkinliğine ilişkin bir araştırma. İstanbul: Türkmen Kitapevi.

Ayboğa, H. (2003). Globalleşme sürecinde ülkemizde muhasebe mesleği ve meslek mensuplarının eğitimi. Marmara Üniversitesi Iktisadi ve Idari Bilimler Dergisi, 18(1), 327-359.

Aygün, D. (2013). Yaratıcı muhasebe stratejileri. Eskişehir Osmangazi Üniversitesi iktisadi ve Idari Bilimler Dergisi, 8(2), 49-69.

Balıkçı, H. (2016). Yaratıcı muhasebe nedenleri, yöntemleri ve sonuçları (Tez no. 425569) [Yüksek lisans tezi, İstanbul]. Ulusal Tez Merkezi. https://tez.yok.gov.tr/UlusalTezMerkezi/tezDetay.jsp?id= s11sAkeCFgeMfcC5U5ANoA\&no=SopptH3KiKkmhqo7QbMOMw

Ball, R., Kothari, S. \& Robin, A. (2000). The effect of international institutional factors on properties of accounting earnings. Journal of Accounting and Economics, 29(1), 1-51.

Barth, M., Landsman, W.R., Lang, M.H. \& Williams, C. (2006). Accounting quality: international accounting standards and US GAAP. http://www.accountancy.smu.edu.sg/research/seminar/pdf/MaryBARTH_paper. pdf

Bayraklı, H.H. (2007). Genel vergi hukuku. Trabzon: Derya Kitabevi.

Bharath, S., Sunder J. \& Sunder S.V. (2006). Accounting quality and debt contracting. http://papers.ssrn.com/sol3/papers.cfm?abstract_id=591342,

Bozkurt, N. (2018). Muhasebe denetimi. İstanbul: Alfa Yayınları.

Bozkurt, N. (2009). Iş̧letmelerin kara deliği hile, çalışan hileleri. İstanbul: Alfa Yayınları.

Callen, J.L., Khan, M. \& Lu, H. (2013), Accounting quality, stock price delay, and future stock returns. Contemporary Accounting Research, 30(1): 269-295. https://doi.org/10.1111/j.1911-3846.2011.01154.x

Can, A. V. \& Demirci, Ş. D. (2016). Uluslararası muhasebe eğitim standardı 2 muhasebe eğitim programlarının içeriğine uyum: Sakarya Üniversitesi örneği. Uluslararası Yönetim iktisat ve Iş̧letme Dergisi, 12(12), 319-338.

Can, A.V. (2010). Krizin muhasebesi ve muhasebenin krizi. Mali Çözüm Dergisi, 97, 21-48.

Carcello, J. V., Hermanson, D. R., Neal, T. L., \& Riley Jr, R. A. (2002). Board characteristics and audit fees. Contemporary Accounting Research, 19(3), 365-384.

Chen, Y., Che, L., Zheng, D., \& You, H. (2020). Corruption culture and accounting quality. Journal of Accounting and Public Policy, 39(2), 1-22. https://doi.org/10.1016/j.jaccpubpol.2019.106698

Chen, H., Tang, Q., Jiang, Y., \& Lin, Z. (2010). The role of international financial reporting standards in accounting quality: evidence from the european union. Journal of international Financial Management \& Accounting, 21(3), 220-278.

Coşkun, Y. (2008). Bankalarda öz disiplin süreçlerinin etkinliğinin değerlendirilmesi. Ankara: Sermaye Piyasası Kurulu Yayını, Yayın No: 210.

Crosby Philip, B. (1979). Quality is free: the art of making quality certain. New American Library.

da Paixão Duarte, A. M., Saur-Amaral, \& mo Azevedo, G. M. (2015). IFRS Adoption and Accounting Quality a Review. Journal of Business \& Economic Policy, 2(2), 104-123. 
Çetenak, E.H, Köse E., \& Bekci, I. (2021). Yolsuzluk ve muhasebe kalitesi ilişkisi. Mehmet Akif Ersoy Üniversitesi iiBF Dergisi, 8(1):215-230. https://doi.org/10.30798/makuiibf.858635

Demir, B. (2005). Muhasebe bilgi sistemlerinde bilgi güvenliği. Muhasebe ve Finansman Dergisi, 26, 147-156.

Demir, M. \& Arslan, Ö. (2020). Muhasebe meslek mensuplarını hile eylemine yönelten psikolojik ve ekonomik faktörler. Anemon Muş Alparslan Üniversitesi Sosyal Bilimler Dergisi, 8(3), 903-911. https://doi.org/10.18506/anemon.662936

Demir, M. \& Eker, A. (2017). Muhasebe meslek mensuplarının vergi aflarının etkinliğine yönelik görüşleri: sivas ilinde bir araştırma, International Journal of Academic Value Studies (Javstudies), Vol:3, Issue:14; pp:237-248 (ISSN:21498598)

Demir, M., Ülker, Y., \& Şenol, M.M. (2020). Muhasebe temel kavramları açısından muhasebe uygulamalarının değerlendirilmesi: Sivas ilinde bir araştırma. İ̧̧letme Araştırmaları Dergisi, 12 (2), 1358-1372. https://doi.org/10.20491/isarder.2020.917

Doğan, í. (2016). Denetim komitesinin finansal raporlama kalitesi üzerindeki etkisi (Tez no. 425278) [Yüksek lisans tezi, Celal Bayar Üniversitesi]. Ulusal Tez Merkezi. https://tez.yok.gov.tr/ UlusalTezMerkezi/tezDetay.jsp?id=LNp7hE_a8_3hS6ObQOiyGQ\&no=00Nba2AUjxv2YnNcqzL_RQ

Durak, G. \& Gürel, E. (2014). Finansal raporların kalitesine etki eden ülkeye özgü faktörler. Muhasebe ve Finansman Dergisi, Ekim Sayısı, 95-110.

Durmuş C. N. \& Taş O. (2008). SPK düzenlemeleri ve 3568 sayılı mevzuat kapsamında denetim. İstanbul: Alfa Yayınları.

Durmuş, H. \& Aytulun, A. (2016). Muhasebe mesleğini ilgilendiren ulusal ve uluslararası kuruluşlar, risk tabanlı denetim ve denetim standartları. TMUD Yayınları: Kitap No: 11.

Durmuş, A.F. \& Güneş, R. (2017). Türkiye'deki yeminli mali müşavirlerin kültür bazlı muhasebe değerlerinin analizi. Muhasebe ve Finansman Dergisi, 76, 81-98. https://doi.org/10.25095/mufad.400220

Durmuş, A.F. \& Sekizsu, H. (2017). Muhasebe meslek mensuplarının mesleki değerlendirmeleri ve sorunlarının analizi: Malatya ili örneği, International Journal of Academic Value Studies (Javstudies) Vol:3, Issue:16; pp:429-438 (ISSN:2149-8598)

Durukan, M.B. \& Kapucugil íkiz, A. (2007). Denetim kalitesi, kalite ve hizmet kalitesine ilişkin modeller: kavramsal çerçeve. Mali Çözüm Dergisi, 82, 29-56.

Ehab M. \& Mostaque, H. M. (2005). The role of audit committees in enhancing a transparent corporate reporting. Humanomics, 1(2), 19-35.

Ertan, Y. (2011). Türkiye muhasebe standartları'nın denetim ve muhasebe kalitesi üzerindeki etkisi: bir uygulama (Tez no. 312276) [Doktora tezi, Uludağ Üniversitesi]. Ulusal Tez Merkezi. https://tez.yok.gov.tr/UlusalTezMerkezi/tezDetay.jsp?id=IWnlriE-HbNvsh18PdranQ\&no=6a7REtLj0vgJ8srgEGrOg

Esendemir, E. (2011). Bağımsız denetim kalitesi ile ilgili yeni yaklaşımlar ve İzmir ilinde yeminli mali müşavirlere yönelik bir araştırma (Tez no. 296613) [Doktora tezi, Celal Bayar Üniversitesi]. Ulusal Tez Merkezi. https://tez.yok.gov.tr/UlusalTezMerkezi/tezDetay.jsp?id=KgDI5tkIE4k00YR2A15a-\&no=XhrUYkyfgrChhdx31jY9Dw

Ezeani, S., Ogbonna, I., Ezemoyih M. \& Okonye, E. (2012). The effect of creative accounting on the job performance of accountants (auditors) in reporting financial statement in Nigeria. Kuwait Chapter of Arabian Journal of Business and Management Review, 1(9),1-30.

Goldberg, S. R. \& Godwin, J. H. (1997). International differences in financial reporting: What US CFOs need to know. Journal of Corporate Accounting \& Finance, 8(2), 93-102.

Gray, S. J. (1988). Towards a theory of cultural influence on the development of accounting systems internationally. Abacus, 24(1), 1-15.

Gücenme Gençoğlu, Ü. \& Ertan, Y. (2012). Muhasebe kalitesini etkileyen faktörler ve Türkiye'deki durum. Muhasebe ve Finansman Dergisi, 53, 1-24. 
Güredin, E. (2014). Denetim ve güvence hizmetleri. İstanbul: Türkmen Kitapevi.

Güvemli, O. (2009). Türkiye'de muhasebe meslek örgütünün 20. yılı-bir değerlendirme. Muhasebe ve Finansman Dergisi, 44, 6-16.

Güvenç, N. (2005). Mersin ilinde bağımsız çalışan muhasebe meslek mensuplarının muhasebe kültür değerleri. (Yayımlanmamış yüksek lisans tezi). Sakarya Üniversitesi.

Hatunoğlu, Z., Koca N. \& Kıllı, M. (2012). İç kontrolün muhasebe sistemindeki hata ve hilelerin önlenmesindeki rolü üzerine bir alan çalışması. Mustafa Kemal Üniversitesi Sosyal Bilimler Enstitüsü Dergisi, 9(20), 169-189.

Hofstede, G. (1983). The cultural relativity of organizational practices and theories. Journal of International Business Studies, 14(2), 75-89.

Hofstede, G. (1991.) Cultures and organizations- software of the mind. New York: McGraw- Hill.

Hofstede, G. (2011). Dimensionalizing cultures: the hofstede model in context. Online Readings in Psychology and Culture, 2(1), 1-25.

Hofstede, G. \& McCrae, R. R. (2004). Personality and culture revisited: linking traits and dimensions of culture. CrossCultural Research, 38(1), 52-88.

Işgüden, B. (2007).Sosyal ve kültürel değerlerin muhasebe meslek etiği üzerine etkileri (Tez no. 206646) [Yüksek lisans tezi, Balıkesir Üniversitesi]. Ulusal Tez Merkezi. https://tez.yok.gov.tr/ UlusalTezMerkezi/tezDetay.jsp?id=DyzOX4hyixF5Dm2lofMDQ\&no=mUm95GOIBSvCMESL_w9bYQ

Jaggi, B. \& Low, P.Y (2000). Impact of culture, market forces and legal system on financial disclosures. The International Journal of Accounting, 35(4), 495- 519.

Jun-bo, S. \& Hai-zhong, Y. (2011). Analysis of accounting disclosure quality in capital markets: current situation and impact factors. Management Science and Industrial Engineering (MSIE), Harbin, 699-703.

Nam, J., Sesay, J. B., Wynne, K., \& Zhang, G. (2020). Financial efficiency and accounting quality: The impact of institutional micro-factors on FDI. Journal of Policy Modeling, 42(2), 451-465. https://doi.org/10.1016/j.jpolmod.2019.12.004

Kalmış, H. \& Dalgın, B.(2010). Muhasebe bilgilerinin karar almada kullanımının önemi ve Çanakkale'de faaliyet gösteren sanayi işletmelerinde bir uygulama. Muhasebe ve Finansman Dergisi, 46, 112-128.

Kamu Gözetimi, Muhasebe ve Denetim Standartları Kurumu. Büyük ve Orta Boy İşletmeler İçin Finansal Raporlama Standardı Hakkında Tebliğ. Resmi Gazete Tarihi:29.07.2017, R. Gazete Sayısı: 30138. Erişim Tarihi: 05.04.202, https://resmigazete.gov.tr/eskiler/2017/07/20170729M1-1.htm

Kamu Gözetimi, Muhasebe ve Denetim Standartları Kurumu. Finansal Raporlamaya Illişkin Kavramsal Çerçeve. Resmi Gazete Tarihi:27.10.2018, R. Gazete Sayısı: 30578. Erişim Tarihi: 07.04.2021, https://resmigazete.gov.tr/eskiler/2018/10/20181027.htm

Karabayır, M.E. (2019). Muhasebe kalitesi ve finansal raporlama. Ankara: Siyasal Kitabevi.

Karadağ, D. (2020). Hofstede'nin kültürel boyutları kapsamında turizm çalışanlarında bölgesel farklııkların incelenmesi (Tez no. 620097) [Yüksek lisans tezi, Karabük Üniversitesi]. Ulusal Tez Merkezi. https://tez.yok.gov.tr/UlusalTezMerkezi/tezDetay.jsp?id=KbaD93nJhvhyrkG8jy-3Gg \&no=UfiW-bCR30p7082u7r$5 \mathrm{jw}$

Karaman, E.S. (2015). Muhasebe meslek etiği ve muhasebe meslek mensuplarının etik kurallara bakışı- Balıkesir ili örneği (Tez no. 421427) [Yüksek lisans tezi, Gazi Üniversitesi]. Ulusal Tez Merkezi. https://tez.yok.gov.tr/UlusalTezMerkezi/tezDetay.jsp?id=5PkuLBQLgfclOpd-QDR2Fg\&no= $\quad$ pT6pVotzIYjRpM$\operatorname{rpd} 8 X I A$

Kardeş Selimoğlu, S. (2014). Denetimin genel çerçevesi. ed. S. Kardeş Selimoğlu \& Ş. Uzay, Muhasebe denetimi, Ankara: Gazi Kitabevi (p. 1-11). 
Kaya, i. (1999). Muhasebe eğitiminde yeniden yapılanma: ABD 'de yaşanan değişim çağı ve değişimin uluslararası boyutu. XVIII. Muhasebe Eğitimi Sempozyumu Tam Metin Kitabı, Fethiye.

Kayıtmaz Balsarı, Ç. \& Dalkılıç, A.F. (2007). Kural bazlı ve ilke bazlı finansal raporlama standartlarının karşılaştırıması. Muhasebe ve Denetime Bakış Dergisi, 22, 105- 118.

Kocacık, F. (2000). Toplum bilim ders notları. Sivas: Cumhuriyet Üniversitesi Yayınları no:84.

Kocamaz, H. (2012). Uluslararası muhasebe standartlarının dünyada ve Türkiye'de oluşum ve gelişim süreci. Kahramanmaraş Sütçü Imam Üniversitesi Iktisadi ve Idari Bilimler Fakültesi Dergisi, 2(2), 105-120.

Köse, E. (2019). Finansal raporlama standartlarının muhasebe kalitesi üzerine etkisi ve bir uygulama (Tez no. 542698) [Doktora tezi, Nevşehir Hacl Bektaş Veli Üniversitesi]. Ulusal Tez Merkezi. https://tez.yok.gov.tr/UlusalTezMerkezi/tezDetay.jsp?id=ljvjiz325zyoPkt_9-Epaw\&no= IO4uWN10pzh9n6ZtTOmYRA

Köse, H. Ö. (2007). Dünyada ve Türkiye'de yüksek denetim. Ankara: TC Sayıştay Yayınları:145.

Kurnaz, N., Ercan, C. \& Kestane, A. (2018). Muhasebe bilgi kalitesi ekseninde iç denetim ve bilgi ifşası (whistleblowing) ilişkisi. Kastamonu Üniversitesi iktisadi ve Idari Bilimler Fakültesi Dergisi, 20(1), 150-169. https://doi.org/10.21180/kuiibf.2018136801

La Porta R., Lopez De Silanes, F., Shleifer, A. \& Vishny, R. W. (1998). Law and finance. Journal of Political Economy, 106(6), 1113-1155.

Maliye Hesap Uzmanları Derneği. (2004). Denetim ilke ve esasları. İstanbul: Acar Matbaası.

Öğücü Şen, F. (2017). Kurumsal yönetişim ve finansal raporlama kalitesi: Türkiye örneği (Tez no. 469151) [Doktora tezi, Gaziantep Üniversitesi]. Ulusal Tez Merkezi. https://tez.yok.gov.tr/ UlusalTezMerkezi/tezDetay.jsp?id=XLe51WrLoMihweVjQbYJpA\&no=oxlhnka9zTsR_ejbP754Rw

Özçelik, H. (2010). Muhasebe bilgi sistemlerince üretilen bilgilerin kalitesini etkileyen kritik başarı faktörleri: IMKB'de bir araştırma (Tez no. 253140) [Doktora tezi, Süleyman Demirel Üniversitesi]. Ulusal Tez Merkezi. https://tez.yok.gov.tr/UlusalTezMerkezi/tezDetay. jsp?id=BxzG2ufMUx6PrV1ljjYeCQ\&no=QIGm3ycH3wfcru6eJpQTxw

Özçelik, H., Karataş Aracı, Ö. N. \& Keskin, S. (2017). Muhasebe hata ve hileleri: meslek mensupları üzerine bir araştırma. Journal of Süleyman Demirel University Institute of Social Sciences, 29(4), 197-214.

Pirgaip, B. (2003). türk sermaye piyasasında uluslararası muhasebe standartlarına uyum. Sermaye Piyasası Kurulu Meslek Personeli Derneği Dergisi, 10.

Pounder, B. (2013). Measuring Accounting Quality: The SEC is developing a software model to measure the accounting quality of its registrants' filings. Accounting Professionals Should Be Aware of The Implications. Strategic Finance, 94(11), 18-21.

Schroeder, R. Clark, M. \& Cathey, J. (2005). Financial accounting theory and analysis. USA: Eighth Edition, Wiley Corp.

Selek, S. (1995). Türkiye'de muhasebe meslek örgütüne yönelik beklentiler, muhasebenin tarihsel ve çağdaş konumlarından geleceğe bakış. Ankara: TÜRMOB Yayınları No:23.

Sermaye Piyasası Kurulu. Sermaye Piyasasında Bağımsız Denetim Standartları Hakkında Tebliğ. Seri: X, No: 22, Resmi Gazete Tarihi: 12.06.2006, resmi Gazete Sayısı: 26196. Erişim Tarihi: 18.03.2021, https://www.resmigazete.gov.tr/eskiler/2006/06/20060612M1.htm.

Soderdstorm, N.S. \& Sun, K.J. (2007). IFRS adoption and accounting quality: A review. European Accounting Review, 16(4), 675-702.

Stolowy, H. \& Breton, G. (2000). A review of research on accounts manipulation. Paper for The Annual Congress of European Accounting Association, Munich, Germany.

Sun, J. (2005). Financial reporting quality, capital allocation efficiency and financing structure: an international study. Doctoral desertion, University of Colorado-Department of Accounting, ABD. 
Temiz, H (2018). Tahakkuk kalitesi ve kârın süreğenliği arasındaki ilişkinin incelenmesi: BIST 100 örneği. Muhasebe ve Finansman Dergisi, Temmuz Sayısı, 81-94. https://doi.org/ 10.25095/mufad.438774

Tükenmez, M. \& Kutay, N.(1998). Muhasebe eğitiminde meslek ahlakının yeri ve önemi. Manisa, Celal Bayar Üniversitesi iktisadi ve Idari Bilimler Fakültesi Yönetim ve Ekonomi Dergisi, 4, 441-452.

Türedi, H. \& Tepegöz, Ş. (2018). Finansman şirketlerinde iç kontrol yapısı yöntemi. Öneri Dergisi, 13(50), 138-158. https://doi.org/10.14783/maruoneri.v13i38778.410464

Türk, M. \& Arslan, M.C. (2017). Yöneticileri yaratıcı muhasebe uygulamalarına iten nedenler ve bir şirket örneği. Gazi iktisat ve Işletme Dergisi, 3(3), 91-108.

Usul, H. (2013). Bağımsız denetim. Ankara: Detay Yayıncılık.

Uzay, Ş. (2014). Denetim süreci ve aşamaları. ed. S. Kardeş Selimoğlu \& Ş. Uzay, Muhasebe denetimi, Ankara: Gazi Kitabevi (p. 77-131).

Ülkü, S. (2012). Davranışsal muhasebe. ed. A. Gökgöz, Muhasebenin sosyal yönü, Bursa: Dora Yayınları.

Yılmaz, M. L. (2019). "Quality vs. quantity debate: Is schooling a necessary condition for economic growth?", International Journal of Academic Value Studies, Vol:5, Issue:1 (5th Year Special Issue); pp:143-150 (ISSN:21498598)

Wursten, H. \& Fadrhonc, T. (2012). International marketing and culture. Itim International, 1-9.

3568 Sayılı Kanun Serbest Muhasebeci Mali Müşavirlik ve Yeminli Müşavirlik Kanunu. Resmi Gazete Tarihi:13.06.1989, Resmi Gazete Sayısı:20194. Erişim Tarihi: 22.03.2021, https://www.resmigazete.gov.tr/arsiv/20194.pdf

https://en.wikipedia.org/wiki/Sarbanes\%E2\%80\%930xley_Act, Erişim Tarihi: 14.01.2021.

https://sozluk.gov.tr, Erişim Tarihi: 02.01.2021.

https://tr.wikipedia.org/wiki/Ortak_hukuk, Erişim Tarihi: 08.12.2020.

https://vergidosyasi.com/2017/04/12/tekduzen-muhasebe-sistemi-nedir-tanimi-ilgili-mevzuat, Erişim Tarihi: 02.03.2021.

https://www.kgk.gov.tr/Portalv2Uploads/files/PDF\%20linkleri/Tan\%C4\%B1t\%C4\%B1m/Public_Oversight_Authority_TR .pdf, Erişim Tarihi: 04.01.2021. 